\title{
How do peers promote social inclusion of children with disabilities? A mixed-methods systematic review
}

DOI:

10.1080/09638288.2018.1561955

\section{Document Version}

Accepted author manuscript

Link to publication record in Manchester Research Explorer

\section{Citation for published version (APA):}

Woodgate, R., Gonzalez, M., Demczuk, L., Snow, W., \& Kirk, S. (2019). How do peers promote social inclusion of children with disabilities? A mixed-methods systematic review. Disability and Rehabilitation .

https://doi.org/10.1080/09638288.2018.1561955

\section{Published in:}

Disability and Rehabilitation

\section{Citing this paper}

Please note that where the full-text provided on Manchester Research Explorer is the Author Accepted Manuscript or Proof version this may differ from the final Published version. If citing, it is advised that you check and use the publisher's definitive version.

\section{General rights}

Copyright and moral rights for the publications made accessible in the Research Explorer are retained by the authors and/or other copyright owners and it is a condition of accessing publications that users recognise and abide by the legal requirements associated with these rights.

\section{Takedown policy}

If you believe that this document breaches copyright please refer to the University of Manchester's Takedown Procedures [http://man.ac.uk/04Y6Bo] or contact uml.scholarlycommunications@manchester.ac.uk providing relevant details, so we can investigate your claim.

\section{OPEN ACCESS}




\title{
How do peers promote social inclusion of children with disabilities? A mixed- methods systematic review
}

\author{
Roberta Woodgate ${ }^{1}$ \\ Miriam Gonzalez ${ }^{1}$ \\ Lisa Demczuk ${ }^{1}$ \\ Wanda Snow ${ }^{1}$ \\ Sarah Barriage ${ }^{1}$ \\ Susan Kirk ${ }^{2}$
}

\footnotetext{
${ }^{1}$ University of Manitoba, Canada

${ }^{2}$ University of Manchester, UK
} 


\title{
How do peers promote social inclusion of children with disabilities? A mixed- methods systematic review
}

\begin{abstract}
Purpose: This mixed-methods systematic review synthesized findings from studies published between January 1, 2006 and July 31, 2018 on the social inclusion experiences of children with and without disabilities, as viewed from their own perspective, with a focus on how typically developing peers promote social inclusion.

Method: Forty-five studies met the inclusion criteria. Data from included studies were synthesized by means of content analysis.

Results: The findings detail the inner social inclusion experiences (e.g., feeling included, different) of children with disabilities and provide information regarding the influence of disability type (e.g., physical, social, affective) on typically developing peers' responses (e.g., acceptance vs. rejection), peers' explanations for social inclusion/exclusion, and peers' relationships with children with disabilities. Barriers to social inclusion, supports, as well as strategies used to promote social inclusion, as perceived by peers and children with disabilities, are also reported.

Conclusion: The findings of this review provide evidence that despite society's efforts to promote social inclusion, children with disabilities continue to report feeling lonely and excluded, having limited contact socially outside of home, and encountering systemic barriers (e.g., bullying, discrimination). More research on the social inclusion experiences of children with disabilities beyond educational settings is needed, such as in the contexts of recreation and leisure, community, and employment. Word count: 208
\end{abstract}

Keywords: children with disabilities, typically developing peers, social inclusion, barriers, supports, friendships 


\section{Introduction}

Globally, approximately 150 million children (under age 18) live with a disability (ies) [1]. These children face multiple barriers that limit their participation in society: negative attitudes, inadequate policies, inaccessible built environments (e.g., buildings, roads) and transportation, unequal access to healthcare, social services, and education, as well as lack of accessible communication and information [2-4]. In addition to limiting societal participation, such barriers increase the risk of negative outcomes for children with disabilities, including reduced educational attainment and employment as well as increased poverty, discrimination, and exclusion relative to their typically developing peers [2,3,5-10]. Barriers faced by children with disabilities also pose significant negative impacts on health status and quality, including poorer health, increased frequency and length of hospitalizations, and decreased coordination of care [3].

The lack of consensus on a definition of disability and the dearth of scientific data on disability issues have made it difficult to make evidence-informed decisions aimed at addressing the needs of children with disabilities, including their degree of inclusion in society [3]. Likewise, social inclusion has been defined in different ways across sectors $[3,11]$. In 1989 , the United Nations called for the protection of the fundamental human rights of children with disabilities, including their right to inclusion in society [12]. Since then, law and policy in some countries have shifted towards education and community inclusion of children with disabilities $[3,11,13]$ such that social inclusion is increasingly seen as a basic human right rather than a privilege $[3,11]$. In addition to addressing issues of human rights and social justice, social inclusion can combat negative attitudes and discrimination regarding those with disabilities [14]. For example, in a study by Favazza and Odom [15], typically developing peers in inclusive 
classrooms (that included discussions about disabilities) had more positive attitudes towards individuals with disabilities in general compared to those in classrooms without peers with disabilities. Social inclusion can also enhance the development and quality of social experiences of children with disabilities $[13,16]$. Thus, data indicate benefits of social inclusion to both children with disabilities and their typically developing peers.

To date, a number of systematic reviews have synthesized the literature on the inclusion of children with disabilities. In general, these reviews have focused on specific topic areas, including: (1) the impact of inclusive education on children with and without disabilities [17-19]; (2) the perspectives of parents, educators, and typically developing peers on inclusive education [20-24]; (3) the perspectives of youth with disabilities regarding the impact of the environment on their participation at school, home, and community [25]; (4) inclusion in physical education [26]; (5) the impact of peer-mediated interventions (PMIs) on children with and without specific disabilities [27-30]; and (6) the social relationships and friendships of children with developmental disabilities [13,31]. Whereas these reviews have advanced our understanding of the inclusion experiences of children living with disabilities, they have tended to focus on the experiences of inclusion within educational settings, with little documentation of inclusion experiences for these children across sectors (e.g., community) and contexts (e.g., family). As well, most of the reviews have focused on children with specific disabilities.

To our knowledge, there is no recent systematic review on the social inclusion experiences of children living with and without disabilities, where: (1) "disabilities" is an encompassing term that refers to any of many chronic physical, mental, intellectual, behavioural, social, and emotional illnesses and disabilities; (2) the focus is on social inclusion experiences beyond educational settings; and (3) the experiences of social inclusion and strategies for its 
promotion from the perspectives of typically developing peers are taken into account. A synthesis of the empirical evidence regarding social inclusion across disabilities and contexts as well as from the perspectives of both children living with disabilities and their typically developing peers would greatly enhance our understanding of the social inclusion experiences of children, which is critical to facilitate inclusion of children with disabilities across societal domains. Examining the perspectives of children with and without disabilities on the ways in which peers promote social inclusion is necessary in order to develop a full understanding of this phenomena, as these groups of children play different roles in the inclusion process.

In order to address these gaps in the literature, the purpose of this mixed-methods systematic review was to synthesize the best available evidence on the social inclusion experiences of children with and without disabilities, including how typically developing peers promote social inclusion of children with disabilities. For the purposes of this review, children with disabilities refers to children living with one or more physical, mental, intellectual, behavioural, social, and emotional illnesses and disabilities, who may require multiple services, from a variety of sectors, and from multiple locations [9,32]. Social inclusion refers to the equal and active participation of children with disabilities in settings such as the school, community (e.g., playgrounds and religious settings), and family and peer events (e.g., birthday parties and sleepovers) $[3,4,11]$. A protocol of this systematic review was published following a preliminary review of the literature and before searching all databases of interest using the strategy formulated for this review [33]. 


\section{Methods}

\section{Search Strategy}

An initial search was conducted to locate any existing systematic reviews or review protocols on the same topic in the following resources: Prospero, Cochrane Library, Joanna Briggs Institute EBP Database, Epistemonikos, Campbell Collaboration, and Google Scholar. Following that, a limited search using an initial set of keywords for children with complex care needs, social inclusion, and peers, was done in the ERIC and CINAHL databases in order to identify further relevant keywords and subject headings. The final search strategy was developed using keywords and subject headings combined by relevant Boolean (AND, OR) and proximity operators. The concept of children living with disabilities was searched using subject headings and related keywords for children and adolescents combined with subject headings for disabled children, chronic disease, and specific childhood developmental disorders, as well as keywords for disabilities or complex care needs and conditions. The concept of social inclusion was searched using subject headings for interpersonal relations, social inclusion, exclusion, participation, friendship, and bullying, as well as keyword phrases for inclusion, participation, integration, acceptance, and belonging. The final concept included subject headings of peer group and friends as well as related peer, friends, and social network keywords. The searches for each concept were then combined using the AND operator.

The search strategy was then adapted for each database. The search was run on February 13, 2017 and updated on August 1, 2018 in the following databases: ERIC (ProQuest), CINAHL (Ebsco), Medline (Ovid), Academic Search Complete (Ebsco), PsycINFO (ProQuest), Social Sciences Citation Index (Thomson Reuters), and Child Development and Adolescent Studies (Ebsco). The search was limited in each database to English language results and publication 
dates from 2006 to the search date. Search results were imported into RefWorks (a reference management software) where duplicates were identified and removed. All references of included articles were probed for additional studies. The search strategy for the Medline database is reported in Supplementary Table S1.

\section{Study Selection}

Studies that: (1) focused on the social inclusion experiences of children living with and without disabilities (aged 2 to 17 years); (2) used a qualitative, quantitative, and/or mixedmethods research approach; (3) were written in English; and (4) were published between January 2006 and July 2018 met the inclusion criteria and were screened further. Studies examining social inclusion experiences across a wide range of activities (e.g., peer social events, family social activities) and community settings, including schools, playgrounds, community centres, religious settings, and children's homes, were selected. Studies were excluded if they were based on data irrelevant to the review question; included young adults (those 18 years of age and older) in study population; exclusively focussed on teacher and/or parent views of social inclusion; nonempirical research, and unpublished research.

From this compilation, each study was then classified as "include," "exclude," or "unclear." The full-text version of articles classified as either "include" or "unclear" by one of two reviewers were retrieved for formal review. The two reviewers independently assessed the full-text version of each article using a standardized form that outlined the inclusion criteria. This form was pilot-tested on a sample of studies. 


\section{Quality Assessment}

Two reviewers critically appraised each included study independently using the Mixed Methods Appraisal Tool (MMAT) version 2011 [34] that appraises qualitative, quantitative, and mixed-methods studies. Any disagreements that arose between reviewers were resolved through discussion or with a third reviewer. An overall quality score was derived using the MMAT. For each criterion, a value of 1 was assigned to a "Yes" response, whereas a value of 0 was assigned to a "No" response. The overall quality score was then calculated by dividing the number of "Yes" responses by the number of relevant criteria and multiplying the product by one hundred to yield a percentage. For mixed-methods studies, the appropriate criteria for the quantitative, qualitative, and mixed methods-components are used; the lowest score of the study components is then assigned as the overall quality score [34]. In addition to being practical (taking approximately 14 minutes to complete), the MMAT has been shown to have an intra-class correlation of 0.8 , considered indicative of substantial agreement between reviewers (a.k.a., good interrater reliability) [35].

\section{Data Extraction \& Synthesis}

One reviewer extracted data from selected studies. The data extracted pertained to each study’s author(s), objectives, design, setting, sample characteristics (sample size, age range), outcomes, data collection and analysis methods as well as conclusions. A second reviewer then verified the extracted data. The Preferred Reporting Items for Systematic Reviews and MetaAnalyses (PRISMA) checklist and flowchart guided the reporting of our findings [36].

Study findings that were relevant to the research purpose were first extracted by one reviewer and then verified by a second reviewer. Data from quantitative, qualitative, and mixed- 
methods studies were analyzed separately using content analysis and then integrated as a whole [37]. Data were coded to identify categories, which were then integrated into two main findings: "Experience of social inclusion by typically developing peers" and "Experience of social inclusion for children with disabilities". Any disagreements were resolved by discussion between the two reviewers until consensus was reached.

\section{Results}

\section{Search Strategy and Study Selection}

The search yielded a total of 5,247 articles, with a total of 3,213 articles after duplicates were removed. Of these, 96 articles were selected based on titles and abstract. The full-text versions of studies were retrieved and then reviewed using inclusion criteria, as defined above. Of these, 45 met criteria for final inclusion in this review. The study search and selection processes are outlined in figure 1.

[Insert figure 1 here]

\section{Quality Assessment}

MMAT quality assessment scores were calculated for the included studies, which indicated varying degrees of quality. For instance, for the quantitative and qualitative studies, quality scores ranged from $50 \%$ (meeting two of the four methodological quality criteria) to $100 \%$ (meeting all of the specified criteria). Over half of the mixed-methods studies had an overall quality score of $75 \%$ (i.e., met three of the four methodological quality criteria) (see Supplementary Table S2). 


\section{Study Characteristics}

Quantitative studies ( $\mathbf{n = 8}$ ). The quantitative studies (see table 1) were conducted in the U.S.A, Iran, Europe, and Australia. The studies took place either at primary schools [38-42] or secondary schools [40,42-54] attended by both students with and without disabilities. The type of disabilities or conditions included physical disabilities, intellectual disabilities, attention-deficit/hyperactivity disorder, autism spectrum disorder, cerebral palsy, Down's syndrome, epilepsy, and Rett syndrome $[38,39,41,42,44]$. In two studies, the specific disability was not stated; in these cases, authors noted either the presence of a mild disability [43] or special education needs [40]. Three of the eight studies included typically developing peers $[38,44,45]$. Data were collected via survey questionnaires and sociometric techniques, such as peer nominations.

\section{[Insert table 1 here]}

Qualitative studies ( $\mathbf{n}=\mathbf{2 7})$. The qualitative studies (see table 2) included in this review were conducted in Canada, U.S.A., Europe, Japan, Australia, and New Zealand. Study samples focused on children with disabilities [46-65], children with and without disabilities [66-69], as well as children without disabilities [70-72]. The type of disabilities or conditions included physical disabilities, cerebral palsy, Down syndrome, autism spectrum disorders (including Asperger's syndrome, as previously classified in the DSMIV [73]), intellectual disabilities, learning disabilities, attention-deficit/hyperactivity disorder, Noonan syndrome, brain injury, Spina bifida, cystic fibrosis, post meningococcal disease, severe asthma, and tracheostomy. Study participants were preschoolers [50,62,67,69], primary-school-aged children [46,48-51,55-58,60,65,66,68-70,72], and 
secondary school-aged adolescents $[48,50,52,54,56,59,61,65,66,69-71]$. Only five studies involved recruitment of participants from the community $[47,53,59,63,64]$, whereas all others were conducted in the school setting. Data were collected through interviews, observations, field notes, focus groups, school records review, and photographs.

[Insert table 2 here]

Mixed-methods studies $(\mathbf{n}=\mathbf{1 0})$. The mixed-methods studies (see table 3 ) were conducted in Canada, the U.S.A., Europe, Hong Kong, and Australia. All studies but one took place in a school setting, including preschools [74-77], primary [78-80], and secondary schools $[81,82]$; one study recruited participants from the community [83]. Study samples consisted of children with disabilities $[77,81,83]$, children without disabilities [74,76], and children with and without disabilities [75,78-80,82]. Type of disabilities or conditions included physical disabilities, cognitive and learning disabilities, social/emotional/behavioural disorders, autism spectrum disorders (including Asperger's syndrome), and developmental delay. Data were collected via questionnaires, sociometric techniques (e.g., peer nominations), semi-structured interviews, participant observation, and vignettes.

[Insert table 3 here]

\section{Findings}

Finding 1: Experience of social inclusion by typically developing peers. This

finding details peers' social inclusion experiences with children with disabilities, including 
how they respond to children with disabilities, their perceived barriers and supports to social inclusion, the interactions and roles peers play in friendships with children with disabilities, and strategies peers use or recommend to promote social inclusion.

Acceptance and explanations for social inclusion. Disability type influenced how peers responded or behaved towards a child with a disability. Disabilities that were associated with peer acceptance included: visible disabilities, physical disabilities, learning disabilities, sensorial impairments, speech/language impairments, disabilities that do not affect social problem solving or emotion regulation, and disabilities that interfered minimally with participation $[40,41,44,74,75,77,82]$. In contrast, disabilities that were: invisible, more severe and interfered with participation, and affected social problem solving or emotion regulation (e.g., attentiondeficit/hyperactivity disorder, developmental delay) were associated with peer rejection $[39,41,44,69,74,77,78,82]$. Based on peer nomination data (e.g., children asked to specify who their friends were), children with communication problems, behavioural problems, social/emotional problems, and sensory and/or motor limitations were found to have fewer friends $[38,40,44,78]$ than typically developing peers. Race and age/grade level in addition to disability may also impact peer acceptance $[38,61]$.

Some studies examined peers' decisions to include or exclude a child with disabilities in activities. Reasons for inclusion pertained to ability or competence, absence of equipment (e.g., wheelchair) making it less difficult for the child with disabilities to participate, desire to share with the child with disabilities, and desire to be fair $[71,74,76]$. Lack of interference of the disability with the activity, being aware of a lack of experience on the part of the child with a disability, and minimal functional skills required for the child to participate were also identified 
as reasons for inclusion $[69,74-76]$. One study found that when peers were given information regarding how a child with a disability could participate, $50 \%$ of the children indicated they would include the child when disability did not interfere with performance, whereas only $33 \%$ indicated they would include the child when the disability interfered with performance, indicating that the demands of the proposed activity affect peer selection [74]. Other justifications for exclusion reported in the literature include the child's: ability with or use of a wheelchair; communication problems; conflicts with peers (e.g., being physically aggressive or disruptive); lack of social skills; avoidance of peers and withdrawal behaviour; and preference to speak and play with adults $[69,76,77]$. One study found that peers reject or escape interacting with peers with disabilities as they see them as "awkward," "weird," or "scary" [82].

\section{Barriers and supports.}

Barriers. Typically developing peers perceived the physical presence of teacher assistants (e.g., limited opportunity to speak to child with a disability) and disability-related challenges, such as difficulty with movement and communication (e.g., hard to understand, peers' own lack of proficiency in augmentative and alternative communication), as barriers to social inclusion for children with disabilities $[39,54,70]$. Other barriers noted pertained to children with disabilities' lack of social competence (e.g., inability to display appropriate behaviour), and lack of similarity or common interests with one's own peer group $[45,66,70,71,74]$. Typically developing peers could also be barriers themselves by forgetting about peers with disabilities, deciding not to invite them to play [66], being reluctant to assume the extra responsibility required when interacting with children with disabilities [71], and indicating a preference to be with friends in their friendship group [71]. Typically developing peers also noted that peer influence (e.g., peer 
reactions and thoughts on what is socially acceptable) plays a significant role when deciding whether to develop a friendship with someone with a disability [45,71]. Physical barriers (e.g., living far away from friends, wheelchair inaccessibility of their own house) and dependence on parents for transportation were also noted as barriers to spending time with friends with a disability $[54,68,70]$.

Supports. Peers without disabilities perceived school and, more specifically, studying in the same classroom, as an appropriate setting (e.g., access, proximity) to get to know peers with disabilities $[45,71,82]$. Educating about disabilities and creating opportunities to participate in the same activities were seen as the school's responsibility [45,71]. Group-based approaches to learning (e.g., peer tutoring, cooperative learning) and special school services (e.g., support rooms where children with disabilities receive additional help) were considered facilitators of social inclusion $[55,71]$. The facilitation of friendships by school professionals (e.g., teachers, school psychologists) by teaching all students how to interact with each other [45] was seen as important. In one study, typically developing students reported that adults can act as interpreters or mediators for a child with a disability and that classroom interaction can be more positive because paraprofessionals discourage harassment or belittling [71]. In another study, staff were observed initiating social interactions between children with and without disabilities directly or indirectly [62]. Direct approaches involved asking the child with a disability to perform an activity with a peer or taking the child to play next to a peer, whereas indirect approaches involved interpreting what the child with a disability wished from a situation as well as helping, modeling actions children could try with others, or just being there with the child [62]. Peers indicated they enjoyed providing support (e.g., physical assistance, providing instructions, 
looking out for one another), considered supports positive for both the child with a disability and themselves, and valued their role in facilitating friendships $[45,66,68]$.

Typically developing peers also recognized the significant role parents of children with disabilities play in facilitating social inclusion [45,70]. In one study, typically developing peers indicated seeing their friends outside of school but that this necessitated help from the parents of the child with a disability in terms of access around stairs, seating, and travel [70]. In another study, typically developing students indicated believing that parents are instrumental in facilitating friendships and that parents should work with schools, teachers, support groups and youth organizations to facilitate friendships [45].

Interactions with peers. Outside of school, typically developing peers reported spending little time with peers with disabilities, and when they did (at parties, sleepovers, trips to movies or shops), this was facilitated by parents $[70,71]$. However, they reported trying to engage with peers with disabilities when at school [70,71]. In addition to peer reports of engaging with children with disabilities, such interactions have also been observed and documented in the literature. For example, in one case study examining the relationship between a child with severe disability and a typically developing peer, the researcher observed several occasions of the peer seeking out and engaging with the child with a disability: sitting with him during lunch, playing with his hands, standing in front of him and making faces at him [60]. Although children with disabilities reported engaging in different types of activities relative to their friends without disabilities (e.g., children with disabilities more frequently participated in adapted sport or sedentary behaviour, such as video games, than those without disabilities), typically developing 
peers reported celebrating their friends' skills and engaging in quieter pastimes (e.g., crafts, board games, television) when with peers with disabilities $[68,70]$.

Friendships. Notwithstanding barriers, typically developing peers reported that forming friendships with peers with disabilities was possible, though not easy, and that these friendships were beneficial to both students with and without disabilities [45]. Typically developing children reported that disability or differences in their peers ignited their initial interest in forming friendships and that altruism, liking to help people, feeling good for helping, and recognition for helping were motivators for initiating friendships [45,70]. Qualities of the typically developing peer (e.g., tendency to attach to peer with disabilities, need to alleviate loneliness) and of the peer with disabilities (e.g., engaging personality, being seen as a nice person) also influenced friendship motivation [70]. Typically developing peers noted that friendships with children with disabilities: (1) were not reciprocal; (2) required patience, a strong sense of obligation, and responsibility; (3) relied on mutual understanding, intimacy, and trust; and (4) were facilitated by similar interests $[68,70,71]$.

Friendship roles. In their relationships with children with disabilities, typically developing peers reported assuming various roles that included: carer, helper, companion $[60,64,70,71]$, protector $[57,70,71]$, communicator and facilitator $[70,71]$. When helping students with disabilities, typically developing peers showed empathy, protectiveness, and support [78]. Further, these peers saw acceptance of differences, recognition of abilities and challenges, and respect as important to promoting social inclusion and establishing relationships with children with disabilities [68]. Typically developing peers deemed friendships with children with disabilities as important, irrespective of their recognition of challenges associated with such relationships [70]. As such, typically developing peers reported using various strategies to 
promote social inclusion and suggested strategies for use by peers as well as teachers (see table 4).

[Insert table 4]

Finding 2: Experience of social inclusion for children with disabilities. This finding details the perspectives of children with disabilities regarding their feelings of social inclusion and acceptance, interactions with others, barriers and supports encountered, and how they counter disablement.

Feelings of social inclusion and acceptance. Whereas some children with disabilities reported feeling included, having a positive sense of belonging, and feeling their peers treated them like anyone else $[46,79,81]$, others reported feeling excluded and lonely $[48,65,79]$. "Feeling included" was associated with having friends, having support from friends, being invited to play, having opportunities to participate in activities, and having a sense of legitimacy as a participant [50,63]. Children with disabilities were observed initiating and participating in social interactions and activities with peers: talking, telling jokes, and laughing together [50,56,79]. One study found that feelings of legitimacy and inclusion depended on how children felt about their activity roles (e.g., making contributions, having important roles) as well as their perspectives of how others viewed and treated them [63]. Having multiple disabilities and feelings of loneliness or not fitting in were also identified as negatively influencing a sense of social inclusion [81].

In terms of social acceptance, studies report varying degrees to which children with disabilities felt accepted by their peers. For example, whereas one study found that children with disabilities experienced equivalent acceptance as their typically developing peers [41], other 
studies found children with disabilities had difficulty being accepted $[77,81]$ or were less accepted than typically developing peers $[40,80]$. Indeed, some studies have found that children are more likely to include a typically developing child or doll in play activities than a child with a disability [74-76]. However, children with disabilities reported feeling accepted (42\%) and fitting in (40\%) "quite a lot" [81]. Their sense of value and acceptance was associated with academic achievement [58], whereas their sense of social acceptance was associated with social participation in leisure time [42].

In addition to reports of feeling accepted, children with disabilities, however, also reported feeling different, being aware of their difference, and having to work hard to keep up in with their peers $[48,50,56,57,59,66,81,83]$. Children were also aware of being treated differently by typically developing peers and teachers and of differences in support service needs as compared to those without disabilities $[56,66]$. They also reported feeling lonely, being an outsider, and not feeling at ease with peers $[40,50,54,56,58,64,65,81,83]$. In one study, students with disabilities reported feeling lonely when eating whether by themselves or with a group [81]. In another study, children with disabilities indicated choosing to be separate from their peers because their own interests differed from those of their peers [58]. School policy and peers' actions also contributed to these experiences of social isolation [58].

Interactions with peers. Children with disabilities reported having limited contact with the social world outside of home and school (with people in general) and limited opportunity to engage with peers in typical childhood activities, such as birthday celebrations $[47,48,80]$. They reported interacting and spending a great proportion of their time with adults, whether at home, school, or local shops $[47,50,81]$. They also reported interacting with siblings (their closest 
relationship) and classmates $[47,81]$. One study found that students with autism spectrum disorders and sensory and/or motor limitations had significantly less interaction with their peers at school than typically developing children [44]. However, although children with disabilities reported enjoying interacting with classmates, being seen as a "baby" and being "mothered" by peers was not experienced positively $[67,81]$. Outside of school, children with disabilities reported participating in solitary activities at home (e.g., computer games, watch TV, read books) as well as group activities, such as swimming, but reported rarely participating in organized sport $[47,68]$. One study found that among children with disabilities, their most frequent activity was school work, followed by talking or texting [81]. Participation in extra-curricular activities (e.g., choir, excursions) and "doing nothing" were reported equally in terms of frequency and followed talking and texting [81]. Children with disabilities rated "doing nothing" negatively in terms of loneliness, enjoyment, fitting in, and acceptance [81]. That is, when "doing nothing", children reported feeling the loneliest, enjoying themselves the least, feeling they fitted in least, and feeling accepted the least [81].

Friendships. Some children with disabilities reported valuing friendships and longing for meaningful friendship connections $[48,52,58,59,61,64]$, while others expressed little motivation to make new or strengthen existing friendships [65]. Some children reported happy and positive relationships with "best friends" who did not have a disability [57], whereas others reported negative experiences, including not having a single friend and feeling lonely $[61,81,83]$. Although children with disabilities did form friendships $[64,78]$, they reported having fewer friends than their typically developing peers, and fewer peers considered them friends $[59,78$ 80]. However, children with disabilities overestimated the number of friends they have [40]. When asked about their friends, children with disabilities listed parents, siblings, classmates, 
younger children, pets, researchers, and other adults that provide support, such as educational assistants, and teachers $[47,65,67]$. Whereas one study reported children with disabilities consistently play, seek, and accept help from familiar playmates [62], another study found these children do not consistently play with the same playmates, and that similar play interests and personalities influence choice of playmates [67].

In terms of the characteristics and quality of friendships, children with disabilities indicated companionship, sharing similar interests, being caring and kind, helping and supporting one another (e.g., friends providing class notes or defending them from harassment), and accepting individual differences $[47,52,53,57-59,61,64,81]$ as important attributes of friendships. Sharing similar interests facilitated friendships [53,58,61]. In one study, children noted that best friends served as sources of instrumental (e.g., helping with homework) and emotional (e.g., advice on how to get along with peers) help and guidance [68]. In friendships where both children have a disability, being able to relate and engage in the same adapted activities facilitated experiencing a sense of belonging and strengthened the friendship [46,48]. Friendship challenges reported by these children include difficulties in maintaining peer interactions and friendships and managing or dealing with conflict with peers [48,52,65,79].

\section{Barriers and supports.}

Barriers. Children with disabilities reported encountering disablement in school structures and practices, peer relations, and the sense of self. Disablement related to school structures pertained to accessibility of schools, disabling interactions with teachers (e.g., being called names, being subject to increased surveillance), and challenges in how teachers interpreted their agency and supported them in class [56,57]. Practices of schooling such as "ability 
grouping" [57] and being separated from peers for being disruptive $[56,58,66]$ were perceived to limit interactions with peers. Disablement related to peer relations included being rejected, bullied, and monitored by peers, being called names, and being socially isolated $[48,54,56,57,61,66,79,83]$. These experiences had a negative impact on children's psychoemotional well-being (e.g., feeling stigmatized, stressed, controlled, dependent) $[57,66]$ and sense of self $[57,58]$. In one study, children with disabilities indicated it was hard for them to maintain a positive self-identify when peers highlighted their differences [58]. In another study, experiences with peers led children with disabilities to consider their sense of self and resist identity imposed on them by peers [57]. Self-disclosure was a way to present themselves in the most favourable light and was also a reaction to fear of stigma or rejection [57]. Whereas some children indicated that disclosing was reserved for friends with the same diagnosis or those they could trust [70], others preferred not to self-disclose [48,57]. Additional barriers encountered and identified by children with disabilities are noted in table 5 .

\section{[Insert table 5]}

Children with disabilities used a variety of strategies to counter disablement and facilitate social inclusion. These are listed in table 6 .

\section{[Insert table 6]}

Supports. Supports experienced by children with disabilities are listed in table 5. Some children with disabilities experienced supports as desirable, whereas others deemed such supports as undesirable. Supports that were considered desirable were those considered good for their development and/or associated with positive consequences (e.g., removed restrictions, allowed them to participate in activities, facilitated social interactions, such as studying together in same classroom) $[50,66,68,82]$. In one study, children with disabilities associated the 
following academic supports with positive academic outcomes: one-on-one support, clear and effective teaching, making the subject interesting, having a friendly teacher, and sitting with peers to work on projects together [43]. Reasons for experiencing supports as undesirable included wanting to be independent [50] and experiencing the support as: stigmatizing; as additional control (e.g., proximity of support person prevents them from chatting with peers); or as enhancing a feeling of dependence or inadequacy [43]. Negative reactions from classmates (e.g., peers being jealous because child gets extra help) [50], perceiving the support as an obstacle to making friends [43], missing out on preferred activities [50], and dreading the extra instruction or use of devices [66] also negatively influenced the way children experienced supports.

\section{Discussion}

This is the first mixed-methods systematic review that sought to advance our understanding on the social inclusion experiences of both children with and without disabilities in a wide range of community settings with attention to identifying social inclusion strategies used by peers without disabilities. Our review and analysis of 45 studies (from January 2006 to July 2018) enrich our understanding of the social inclusion experiences of children with and without disabilities, as reported by children themselves, in several critical ways. Firstly, the findings shed light on the social inclusion experiences of children with disabilities including feelings of inclusion and acceptance, their relationships with peers, and barriers and supports, from their perspectives. Secondly, the findings provide information regarding the influence of disability type (e.g., physical, social, affective) on typically developing peers' responses (e.g., acceptance vs. rejection), peers' explanations for inclusion/exclusion in play, peer relationships 
with children with disabilities, and barriers to social inclusion and supports, as perceived by peers themselves. Finally, through this work we are also able to highlight: (1) strategies used by typically developing peers to promote inclusion, (2) strategies used by children with disabilities to counter disablement and facilitate inclusion, and (3) implications for research and practice.

The findings of this review provide evidence that despite society's efforts to promote social inclusion, children with disabilities continue to report feeling lonely and excluded, having limited contact with the social world outside of home, and encountering systemic barriers (e.g., bullying, discrimination). They also report experiencing supports as undesirable, particularly when supports are associated with feelings of dependency and stigmatization. In fact, children with disabilities reported that the very supports put in place to increase their sense of inclusion can actually become obstacles to making friends or participating in preferred activities, thereby yielding significant unintended consequences, including negatively impacting children's wellbeing and sense of self. These insights demonstrate the critical need to evaluate the implementation of such supports that, although well-intended, may not be positively impacting perceived social inclusion among children with disabilities.

The results of this systematic review also show that despite the implementation of inclusionary practices in educational settings, typically developing peers continue to spend limited time with peers with disabilities outside of school. Thus, the impacts of education-based policies on social inclusion opportunities and the sense of inclusion outside of the academic world appear limited for children with disabilities. Disability-related challenges (e.g., communication difficulties, lack of ability), peer influence, and physical barriers (e.g., wheelchair inaccessibility of their own home) make it difficult to spend time with children with disabilities. The findings also suggest that typically developing peers are more likely to reject 
peers with disabilities not only when the disability interferes with participation (e.g., ability, use of wheelchair) but also when the disability is invisible or affects social problem solving or emotional/affective regulation (e.g., physical aggression, difficulty with social skills).

Irrespective of these challenges, some typically developing peers report not only engaging with children with disabilities at school (and using various strategies to promote social inclusion) but also report that such relationships are valued and important [70]. These findings raise important implications for research and practice.

The reasons for exclusion (e.g., disability interferes with participation, affects social problem solving or emotional/affective regulation) and the barriers to social inclusion (e.g., peer influence), as perceived by typically developing peers, highlight the need for disability education for school-aged children, parents, and teachers. Disability education for typically developing peers in particular is critical in order to remove attitudinal barriers faced by children with disabilities and is supported by research, which has shown that such educational interventions can positively impact typically developing peers' attitudes regarding disability [15]. The review also highlighted supports perceived as barriers to social inclusion (e.g., teacher assistance) by children with disabilities as well as their reasons for experiencing supports either positively or negatively (e.g., barriers). For example, supports were considered desirable when they were associated with positive consequences (e.g., support removes restrictions in activities, facilitates relationships). Therefore, promoting the positive consequences (e.g., can help with work and will only be for a few hours) associated with supports that are perceived as barriers (e.g., teacher assistance) may foster more positive attitudes towards such supports for children with disabilities. 
As noted in this review, typically developing peers report using various strategies to foster social inclusion. These insights underscore the importance of incorporating children's perspectives in activities and programs aimed at promoting social inclusion. These strategies can be useful to professionals and parents who wish to enhance the social inclusion experiences of children with disabilities. The fact that peers' explanations for inclusion pertained to sharing, fairness, and a lack of experience on the part of the child with a disability suggests that promoting equity and giving peers information about the limited participation of children with disabilities may facilitate social inclusion [74].

\section{Future Research}

This review focused on the social inclusion experiences of children with and without disabilities, as reported by children themselves. Future work is needed to synthesize the literature regarding the experiences of inclusion and strategies for its promotion from the perspectives of other individuals, including siblings, professionals who support these children, and parents in order to more fully inform how best to ensure social inclusion for children with disabilities in everyday life.

In the current review, very few studies examined the social inclusion experiences for children with or without disabilities outside of the educational setting. Thus, the results of this review highlight the need for research on the social inclusion experiences of children in settings other than the school, such as in the contexts of recreation and leisure (e.g., games, sports, arts), community (e.g., volunteering, religious activities/organizations), and employment (e.g., older children who work). Moreover, there is a need for more longitudinal studies documenting how children's experiences and needs are influenced by age and how they change over time, 
including during the transition to adulthood $[84,85]$. Such studies are crucial to understand the longer-term impact of a lack of social inclusion on individuals with disabilities across development (e.g., childhood to adulthood) and vantage points (e.g., physical and mental health and well-being, educational and employment status).

Despite the broad scope of this review, very few studies referenced children with disabilities' experiences with assistive devices and their potential impacts on their sense and experiences of social inclusion. This is somewhat surprising, given that the use of assistive devices, including those for use in daily living (e.g., prosthetic/orthotic devices), indoor/outdoor mobility and transportation (e.g., walking devices, wheelchairs), communication (e.g., hearing aids, voice prostheses), and education (e.g., computer technology for the acquisition of knowledge), is common for many children with disabilities, particularly in developed countries. In particular, there is a lack of research on the extent to which use of some of these devices are perceived as barriers and, if so, in what contexts, from the perspectives of children using them and their peers.

The present review sought to synthesize the global literature regarding the experiences of social inclusion for children with disabilities and their typically developing peers from their viewpoints. Importantly, very few of the 45 selected studies were conducted outside North America or Europe. For example, only a limited number of studies were from Asian countries (two studies from Japan; one from Hong Kong), and no studies from Latin America or Africa met the criteria for inclusion in the review. Moreover, none of the studies focused on the social inclusion experiences of Indigenous children. Future research is needed to document the social inclusion experiences of children across various cultures. Such studies are warranted to uncover 
themes that may be common to feelings and experiences of inclusion, irrespective of culture, as well as to identify culturally specific aspects of social inclusion.

Over half $(60 \%)$ of the studies in this systematic review used qualitative methodology, reinforcing the need for more quantitative and mixed-methods studies. As well, the qualitative studies relied mainly on the use of interviews. Combining interviews in conjunction with artsbased participatory methods (e.g., photovoice, artwork, and other visual methods) as Howard et al. [53] did, would be of value in future mixed-methods and qualitative studies. Arts-based participatory methods can be powerful research tools, especially amongst children, and can elicit a deeper awareness of the meanings behind and contexts within descriptions of one's lived experiences $[86,87]$. Data gathered from participatory methods can effectively augment data collected from more traditional qualitative approaches (e.g., interviews), and, thereby, lead to a greater understanding of one's lived experiences [86,87].

Finally, future research should also explicitly consider the impact of societal stigma on typically developing peers' behaviors and attitudes toward children with disabilities. Research that focuses on the strategies that peers can and do use to promote social inclusion of children with disabilities may inadvertently reinforce the perception that disability as a 'problem' that resides with the child and that social exclusion is perpetuated solely by children, and hence that solutions should be targeted at this population. Recognizing broader societal influences on behaviors such as bullying, discrimination, and segregation, as well as the role of adults in facilitating and modeling socially inclusive behaviors, is needed in future work. 


\section{Limitations of Data Synthesized}

This systematic review took a rigorous approach to identifying published studies on the experiences of social inclusion for children with and without disabilities from their point of view. Our mixed-methods approach allowed us to synthesize findings from qualitative, quantitative, and mixed-methods studies, resulting in a more integrated understanding of the social inclusion experiences of children with and without disabilities. Of the studies synthesized herein, some limitations warrant further discussion and highlighting.

First, although the scope of this review was intended to be broad in terms of contexts (e.g., community, recreation, education) of social inclusion, most of the articles retrieved examined inclusion in the school setting, with very few studies taking place in community settings where children interact (e.g., playgrounds, community centres, religious settings, peers' homes). Thus, little is known about the social inclusion experiences of children with and without disabilities in those environments.

Second, very few of the studies reviewed examined experiences of social inclusion over time. Our search and selection strategy revealed only three studies on social inclusion experiences for children with disabilities and/or their typically developing peers were longitudinal $[55,57,69]$. Additionally, the variety of age groups included in individual studies, the diversity in study setting and the depth/detail of data reported limited the ability to conduct an analysis of differences in social inclusion experiences by age.

Third, some of the included studies provided an incomplete definition of the setting in which the study took place. For instance, some studies were conducted in schools with a fullinclusion policy in effect [40], whereas others were conducted in mainstream schools [41,50,51]. However, more complete descriptions and operational definitions of school settings (e.g., 
mainstream school vs. school with a full-inclusion policy) were seldom provided, thus limiting our ability to compare study findings.

A fourth limitation of the selected studies relates to study quality in some cases, as seven $(16 \%)$ of the included studies were considered of low to moderate quality (scores ranged from $25 \%$ to $50 \%$ ). Nonetheless, as these articles contained data relevant to our research questions, they were included. Therefore, the quality of these articles should be kept in mind when evaluating the findings.

A fifth limitation relates to the nature of analyzing published research. Given that this review analyzes the published findings of other authors' research, rather than the rich data each study generated, a detailed comparative analysis of the social inclusion experiences of children with disabilities and their typically developing peers was not possible.

Finally, studies evaluating programs or interventions designed to promote social inclusion were not included in this systematic review, as the focus of the present review was not on program or intervention evaluation but rather on the experiences and strategies used by typically developing peers and children with disabilities to promote social inclusion from their viewpoints.

\section{Conclusion}

This mixed-methods systematic review is important as it revealed that despite the implementation of inclusionary practices in educational settings, children with disabilities continue to feel excluded and encounter systemic disablement. As well, although typically developing peers report using various strategies to foster social inclusion of children with disabilities, they nonetheless continue to spend limited time with peers with disabilities outside 
of school. These two findings reinforce that more needs to be done to reduce barriers to inclusion both inside and outside educational settings for children with disabilities.

Word count: text: 6794

\section{Declaration of Interest}

The authors report no conflicts of interest.

RLW is supported by a Tier 1 Canadian Research Chair (CRC) in Child and Family Engagement in Health Research and Healthcare. She was also supported by a Canadian Institutes of Health Research (CIHR) Applied Chair in Reproductive, Child and Youth Health Services and Policy Research (Grant\#: CIHR APR -126339), (2012-2017).

\section{Implications for Rehabilitation}

The perspectives of children with and without disabilities need to be integrated in activities and programs aimed at promoting social inclusion.

Teaching social inclusion strategies to children with and without disabilities is needed to help them deal with barriers.

In addition to educational settings, rehabilitation clinicians need to promote social inclusion strategies in other contexts such as recreation and leisure, community, and employment contexts. 


\section{References}

1. United Nations Children's Fund (UNICEF). The state of the world's children 2006: excluded and invisible. Unicef; 2005.

2. Green S, Davis C, Karshmer E, et al. Living stigma: The impact of labeling, stereotyping, separation, status loss, and discrimination in the lives of individuals with disabilities and their families. Sociol Inq. 2005;75(2):197-215.

3. World Health Organization (WHO). World report on disability 2011. 2011.

4. United Nations Children's Fund (UNICEF). Promoting the rights of children with disabilities. Innocenti Digest. 2007;13:1-68.

5. Berry JG, Agrawal RK, Cohen E, et al. The landscape of medical care for children with medical complexity. Overland Park, KS: Children's Hospital Association. 2013.

6. Cohen E, Berry JG, Camacho X, et al. Patterns and costs of health care use of children with medical complexity. Pediatrics. 2012;130(6):e1463-e1470.

7. Dewan T, Cohen E. Children with medical complexity in Canada. Paed Child HealtCAN. 2013;18(10):518-522.

8. Elias ER, Murphy NA, Liptak GS, et al. Home care of children and youth with complex health care needs and technology dependencies. Pediatrics. 2012;129(5):996-1005.

9. Schoen C, Osborn R, Squires D, et al. New 2011 survey of patients with complex care needs in eleven countries finds that care is often poorly coordinated. Health Affairs. 2011;30(12):2427-2436.

10. Thornicroft G, Rose D, Kassam A. Discrimination in health care against people with mental illness. Int Rev Psychiatr. 2007;19(2):113-122.

11. Odom SL, Buysse V, Soukakou E. Inclusion for Young Children With Disabilities:A Quarter Century of Research Perspectives. J Early Intervention. 2011;33(4):344-356.

12. United Nations General Assembly. Convention on the Rights of the Child, 20 November 1989, United Nations, Treaty Series, vol. 1577. UN General Assembly; 1989.

13. Webster AA, Carter M. Social relationships and friendships of children with developmental disabilities: Implications for inclusive settings. A systematic review. J Intellect Dev Dis. 2007;32(3):200-213. 
14. United Nations Educational Scientific and Cultural Organization (UNESCO). Understanding and responding to children's needs in inclusive classrooms: a guide for teachers. UNESCO; 2001.

15. Favazza PC, Odom SL. Promoting Positive Attitudes of Kindergarten-Age Children Toward People with Disabilities. Except Children. 1997;63(3):405-418.

16. Boutot EA, Bryant DP. Social integration of students with autism in inclusive settings. Educ Train Dev Disab. 2005;40(1):14-23.

17. Kalambouka A, Farrell P, Dyson A, et al. The impact of placing pupils with special educational needs in mainstream schools on the achievement of their peers. Educ Res. 2007;49(4):365-382.

18. Lindsay G. Educational psychology and the effectiveness of inclusive education/mainstreaming. Brit J Educ Psychol. 2007;77(1):1-24.

19. Ruijs NM, Peetsma TTD. Effects of inclusion on students with and without special educational needs reviewed. Educ Res Rev-Neth. 2009;4(2):67-79.

20. Avramidis E, Norwich B. Teachers' attitudes towards integration/inclusion: A review of the literature. Eue J Spec Needs Edu. 2002;17(2):129-147.

21. Bates H, McCafferty A, Quayle E, et al. Review: Typically-developing students views and experiences of inclusive education. Disabil Rehabil. 2015;37(21):1929-1939.

22. de Boer A, Pijl SJ, Minnaert A. Attitudes of parents towards inclusive education: A review of the literature. Eue J Spec Needs Edu. 2010;25(2):165-181.

23. de Boer A, Pij1 SJ, Minnaert A. Students' Attitudes towards Peers with Disabilities: A review of the literature. Int J Disabil Dev Ed. 2012;59(4):379-392.

24. Gal E, Schreur N, Engel-Yeger B. Inclusion of Children with Disabilities: Teachers' Attitudes and Requirements for Environmental Accommodations. Int J Spec Educ. 2010;25(2):89-99.

25. Kramer JM, Olsen S, Mermelstein M, et al. Youth with disabilities' perspectives of the environment and participation: A qualitative meta-synthesis. Child Care Hlth Dev. 2012;38(6):763-777.

26. Block ME, Obrusnikova I. Inclusion in physical education: A review of the literature from 1995-2005. Adapt Phys Act Q. 2007;24(2):103-124. 
27. Chang YC, Locke J. A systematic review of peer-mediated interventions for children with autism spectrum disorder. Res Autism Spect Dis. 2016;27:1-10.

28. Schaefer JM, Cannella-Malone HI, Carter EW. The Place of Peers in Peer-Mediated Interventions for Students With Intellectual Disability. Rem Spec Educ. 2016;37(6):345356.

29. Wang SY, Cui Y, Parrila R. Examining the effectiveness of peer-mediated and videomodeling social skills interventions for children with autism spectrum disorders: A metaanalysis in single-case research using HLM. Res Autism Spect Dis. 2011;5(1):562-569.

30. Zhang J, Wheeler JJ. A meta-analysis of peer-mediated interventions for young children with autism spectrum disorders. Educ Train Autism De. 2011;46(1):62-77.

31. Petrina N, Carter M, Stephenson J. The nature of friendship in children with autism spectrum disorders: A systematic review. Res Autism Spect Dis. 2014;8(2):111-126.

32. Burnside L. Youth in care with complex needs. Manitoba Office of the Children's Advocate; 2012.

33. Woodgate RL, Gonzalez M, Demczuk L, et al. How Do Peers Promote Inclusion of Children with Disabilities? A Mixed Methods Systematic Review. PROSPERO. 2016.

34. Pluye P, Robert E, Cargo M, et al. Proposal: A mixed methods appraisal tool for systematic mixed studies reviews. Montréal: McGill University. 2011;2:1-8.

35. Pace R, Pluye P, Bartlett G, et al. Testing the reliability and efficiency of the pilot Mixed Methods Appraisal Tool (MMAT) for systematic mixed studies review. International journal of nursing studies. 2012 Jan;49(1):47-53. PubMed PMID: 21835406; eng.

36. Moher D, Liberati A, Tetzlaff J, et al. Preferred reporting items for systematic reviews and meta-analyses: The PRISMA statement. Ann Intern Med. 2009;151(4):264-269.

37. Heyvaert M, Maes B, Onghena P. Mixed methods research synthesis: Definition, framework, and potential. Qual Quant. 2013;47(2):659-676.

38. Azad GF, Locke J, Kasari C, et al. Race, disability, and grade: social relationships in children with autism spectrum disorders. Autism. 2017;21(1):92-99.

39. de Boer A, Pijl SJ, Post W, et al. Peer acceptance and friendships of students with disabilities in general education: The role of child, peer, and classroom variables. Soc Dev. 2013;22(4):831-844. 
40. Pijl SJ, Frostad P, Flem A. The social position of pupils with special needs in regular schools. Scand J Educ Res. 2008;52(4):387-405.

41. Tuersley-Dixon L, Frederickson N. Social inclusion of children with complex needs in mainstream: Does visibility and severity of disability matter? Int J Dev Disabil. 2016;62(2):89-97.

42. Wendelborg C, Kvello T. Perceived Social Acceptance and Peer Intimacy Among Children with Disabilities in Regular Schools in Norway. J Appl Res Intellect. 2010;23(2):143-153.

43. O'Rourke J, Houghton S. Perceptions of secondary school students with mild disabilities to the academic and social support mechanisms implemented in regular classrooms. Int $\mathbf{J}$ Disabil Dev Ed. 2008;55(3):227-237.

44. Petry K. The relationship between class attitudes towards peers with a disability and peer acceptance, friendships and peer interactions of students with a disability in regular secondary schools. Eur J Spec Needs Educ. 2018;33(2):254-268.

45. Shokoohi-Yekta M, Hendrickson JM. Friendships with peers with severe disabilities: American and Iranian secondary students' ideas about being a friend. Educ Train Autism De. 2010;45(1):23-37.

46. Asbjørnslett M, Engelsrud GH, Helseth S. 'Friendship in all directions': Norwegian children with physical disabilities experiencing friendship. Childhood. 2012;19(4):481494.

47. Batorowicz B, Campbell F, Von Tetzchner S, et al. Social participation of school-aged children who use communication aids: The views of children and parents. Augment Altern Comm. 2014;30(3):237-251.

48. Cook A, Ogeden J, Winstone N. Friendship motivations, challenges and the role of masking for girls with autism in contrasting school settings. Eur J Spec Needs Educ. 2018;33(3):302-315.

49. Correa-Torres SM. The nature of the social experiences of students with deaf-blindness who are educated in inclusive settings. J Visual Impair Blin. 2008;102(5):272-283. 
50. De Schauwer E, Van Hove G, Mortier K, et al. 'I need help on mondays, it's not my day. the other days, I'm OK'. - Perspectives of disabled children on inclusive education. Child Soc. 2009;23(2):99-111.

51. Dolva AS, Hemmingsson H, Gustavsson A, et al. Children with down syndrome in mainstream schools: Peer interaction in activities. Eue J Spec Needs Edu. 2010;25(3):283-294.

52. Foggo RSV, Webster AA. Understanding the social experiences of adolescent females on the autism spectrum. Res Autism Spectr Disord. 2017;35:74-85.

53. Howard B, Cohn E, Orsmond GI. Understanding and negotiating friendships: Perspectives from an adolescent with Asperger syndrome. Autism. 2006;10(6):619-627.

54. Kamenopoulou L. A study on the inclusion of deafblind young people in mainstream schools: Key findings and implications for research and practice. Brit J Special Educ. 2012;39(3):137-145.

55. Kayama M, Haight W. The experiences of Japanese elementary-school children living with 'developmental disabilities': Navigating peer relationships. Qual Soc Work. 2013;12(5):555-571.

56. MacArthur J, Sharp S, Kelly B, et al. Disabled children negotiating school life: Agency, difference and teaching practice. Int J Child Rts. 2007;15(1):99-120.

57. McMaugh A. En/countering disablement in school life in Australia: Children talk about peer relations and living with illness and disability. Disabil Soc. 2011;26(7):853-866.

58. Morrison R, Burgman I. Friendship experiences among children with disabilities who attend mainstream Australian schools. Can J Occup Ther. 2009;76(3):145-152.

59. Murphy M, Burns J, Kilbey E. Using personal construct methodology to explore relationships with adolescents with autism spectrum disorder. Res Dev Disabil. 2017;70:22-32.

60. Naraian S. Teacher discourse, peer relations, significant disability: Unraveling one friendship story. Int J Qual Stud Educ. 2011;24(1):97-115.

61. O'Hagan S, Hebron J. Perceptions of friendship among adolescents with autism spectrum conditions in a mainstream high school resource provision. Eur J Spec Needs Educ. 2017; 32(3):314-328. 
62. Parry J. Making connections and making friends: Social interactions between two children labelled with special educational needs and their peers in a nursery setting. Early Years. 2014;34(3):301-314.

63. Spencer-Cavaliere N, Watkinson EJ. Inclusion understood from the perspectives of children with disability. Adapt Phys Act Q. 2010;27(4):275-293.

64. Spratling R, Minick P, Carmon M. The Experiences of School-Age Children With a Tracheostomy. J Pediatr Health Car. 2012;26(2):118-125.

65. Sumiya M, Igarashi K, Miyahara M. Emotions surrounding friendships of adolescents with autism spectrum disorder in Japan: a qualitative interview study. PLoS ONE. 2018;13(2).

66. Mortier K, Desimpel L, de Schauwer E, et al. I want support, not comments: Children's perspectives on supports in their life. Disabil Soc. 2011;26(2):207-221.

67. Parry J. Exploring the social connections in preschool settings between children labelled with special educational needs and their peers. Int J Early Years Educ. 2015;23(4):352364.

68. Seymour H, Reid G, Bloom GA. Friendship in inclusive physical education. Adapt Phys Act Q. 2009;26(3):201-219.

69. Ytterhus B. Everyday Segregation Amongst Disabled Children and Their Peers: A Qualitative Longitudinal Study in Norway. Child Soc. 2012;26(3):203-213.

70. $\quad$ Anderson K, Balandin S, Clendon S. "He cares about me and I care about him." Children's experiences of friendship with peers who use AAC. Augmentative and alternative communication (Baltimore, Md : 1985). 2011 Jun;27(2):77-90. PubMed PMID: 21592003; eng.

71. Kalymon K, Gettinger M, Hanley-Maxwell C. Middle school boys' perspectives on social relationships with peers with disabilities. Rem Spec Educ. 2010;31(4):305-316.

72. Nowicki EA, Brown JD. "A kid way": strategies for including classmates with learning or intellectual disabilities. Intellectual and developmental disabilities. 2013 Aug;51(4):253-62. PubMed PMID: 23909587; eng. 
73. American Psychiatric Association. Diagnostic and statistical manual of mental disorders : DSM-5. 5th ed. Washington, DC: Arlington, VA : American Psychiatric Publishing; 2013.

74. Diamond $\mathrm{K}, \mathrm{Tu} \mathrm{H}$. Relations between classroom context, physical disability and preschool children's inclusion decisions. J Appl Dev Psychol. 2009;30(2):75-81.

75. Diamond KE, Hong SY. Young Children's Decisions to Include Peers With Physical Disabilities in Play. J Early Intervention. 2010;32(3):163-177.

76. Diamond KE, Hong SY, Tu H. Context influences preschool children's decisions to include a peer with a physical disability in play. Exceptionality. 2008;16(3):141-155.

77. Odom SL, Zercher C, Li S, et al. Social acceptance and rejection of preschool children with disabilities: A mixed-method analysis. J Educ Psychol. 2006;98(4):807-823.

78. Avramidis E. Self-concept, social position and social participation of pupils with SEN in mainstream primary schools. Res Pap Educ. 2013 2013/09/01;28(4):421-442.

79. Calder L, Hill V, Pellicano E. 'Sometimes I want to play by myself': Understanding what friendship means to children with autism in mainstream primary schools. Autism. 2013;17(3):296-316.

80. Chamberlain B, Kasari C, Rotheram-Fuller E. Involvement or isolation? The social networks of children with autism in regular classrooms. J Autism Dev Disord. 2007;37(2):230-242.

81. Jessup G, Bundy AC, Broom A, et al. The social experiences of high school students with visual impairments. J Visual Impair Blin. 2017;111(1):5-19.

82. Tsang KLV. Secondary pupils' perceptions and experiences towards studying in an inclusive classroom. Int J Whole Sch. 2013;9(2):39-60.

83. Dewey D, Volkovinskaia A. Health-related quality of life and peer relationships in adolescents with developmental coordination disorder and attention-deficit-hyperactivity disorder. Dev Med Child Neurol. 2018;60(7):711-717.

84. Gray KM, Piccinin A, Keating CM, Taffe J, Parmenter TR, Hofer S, Einfield SL, Tonge BJ. Outcomes in young adulthood: Are we achieving community participation and inclusion? J Intellect Disabil Res. 2014;58(8):734-745. 
85. MacIntyre G. The potential for inclusion: Young people with learning disabilities experiences of social inclusion as they make the transition from childhood to adulthood. $\mathbf{J}$ Youth Stud. 2014;17(7):857-871.

86. Woodgate RL, Zurba M, Tennent P. Worth a thousand words? Advantages, challenges and opportunities in working with photovoice as a qualitative research method with youth and their families. Forum Qual Soc Res. 2017;18(1).

87. Woodgate RL, Zurba M, Tennent P. A day in the life of a young person with anxiety: Arts-based boundary objects used to communicate the results of health research. Forum Qual Soc Res. 2017;18(3). 
Table 1. Quantitative Studies Included in the Systematic Review

\begin{tabular}{|c|c|c|c|c|c|c|c|}
\hline $\begin{array}{l}\text { Author, } \\
\text { Year/ } \\
\text { Country }\end{array}$ & Purpose & $\begin{array}{l}\text { Setting, } \\
\text { Age \&/or } \\
\text { Grade }\end{array}$ & $\begin{array}{c}\text { Data } \\
\text { Collection } \\
\text { Method }\end{array}$ & $\begin{array}{l}\text { Number } \\
\text { (\% Female) }\end{array}$ & $\begin{array}{c}\text { Disability } \\
\text { Type }\end{array}$ & Main Findings & Limitations \\
\hline $\begin{array}{c}\text { Azad et al. } \\
\text { [38] (2017) } \\
\text { USA }\end{array}$ & $\begin{array}{l}\text { Examine how } \\
\text { race, disability } \\
\text { status, \& grade } \\
\text { affect } \\
\text { friendships and } \\
\text { social networks. }\end{array}$ & $\begin{array}{l}\begin{array}{l}\text { Elementary } \\
\text { school }\end{array} \\
4-12 \text { yrs } \\
\text { Mean age: } 7.9 \\
\text { yrs } \\
\text { K - Grade } 5\end{array}$ & $\begin{array}{l}\text { Peer } \\
\text { nominations }\end{array}$ & $\begin{array}{l}\mathrm{n}=170 \\
(11.8 \%) \\
\\
85 \text { children } \\
\text { with Autism } \\
\text { Spectrum } \\
\text { Disorders } \\
\text { (ASD); } \\
85 \text { typically } \\
\text { developing } \\
\text { children }\end{array}$ & ASD & $\begin{array}{l}\text { - Race, presence of } \\
\text { ASD, \& grade } \\
\text { influenced the number } \\
\text { of friendship } \\
\text { nominations that } \\
\text { children received. The } \\
\text { presence of ASD } \\
\text { influenced network } \\
\text { centrality. } \\
\text { - African American or } \\
\text { Latino children with } \\
\text { ASD in the upper } \\
\text { elementary grades } \\
\text { received fewer } \\
\text { friendship nominations } \\
\text { than White typically } \\
\text { developing children in } \\
\text { the lower elementary } \\
\text { grades. } \\
\text { - Latino children with } \\
\text { ASD were at the } \\
\text { highest risk of social } \\
\text { isolation. }\end{array}$ & $\begin{array}{l}\text { - Examination of other } \\
\text { variables (gender } \\
\text { homophily, racial } \\
\text { composition of the } \\
\text { classroom, SES) was } \\
\text { not possible given } \\
\text { small sample size. } \\
\text { - Given study design, } \\
\text { examination of } \\
\text { changes in } \\
\text { socialization over } \\
\text { time was not } \\
\text { possible. }\end{array}$ \\
\hline $\begin{array}{l}\text { de Boer et al. } \\
\text { [39] (2013) } \\
\text { (Netherlands) }\end{array}$ & $\begin{array}{l}\text { Examine which } \\
\text { child, peer, and } \\
\text { classroom } \\
\text { variables relate } \\
\text { to peer } \\
\text { acceptance and } \\
\text { friendships of } \\
\text { students with }\end{array}$ & $\begin{array}{l}\begin{array}{l}\text { General } \\
\text { primary } \\
\text { education }\end{array} \\
8 \text {-11 yrs } \\
\text { Grades 5-8 }\end{array}$ & $\begin{array}{l}\text { Sociometric } \\
\text { data collected } \\
\text { via self-report } \\
\text { survey }\end{array}$ & $\begin{array}{l}\mathrm{n}=1050 \\
985 \text { students } \\
\text { without } \\
\text { disabilities; } \\
31 \text { students } \\
\text { with attention- } \\
\text { deficit }\end{array}$ & $\begin{array}{l}\text { ADHD, } \\
\text { ASD }\end{array}$ & $\begin{array}{l}\text { - Boys with disabilities } \\
\text { more likely to be } \\
\text { accepted when class } \\
\text { attitude is positive. } \\
\text { - Boys with disabilities } \\
\text { less likely to be } \\
\text { accepted in classes and } \\
\text { acquire friendships }\end{array}$ & $\begin{array}{l}\text { Bi-directionality of } \\
\text { findings: do social } \\
\text { behavior issues of } \\
\text { students with } \\
\text { disabilities lead to } \\
\text { less peer acceptance } \\
\text { or does the latter }\end{array}$ \\
\hline
\end{tabular}




\begin{tabular}{|c|c|c|c|c|c|c|c|}
\hline & $\begin{array}{l}\text { disabilities in } \\
\text { general primary } \\
\text { education. }\end{array}$ & & & $\begin{array}{l}\text { hyperactivity } \\
\text { disorder } \\
\text { (ADHD); } 34 \\
\text { students with } \\
\text { ASD }\end{array}$ & & $\begin{array}{l}\text { with teacher } \\
\text { assistance. } \\
\text { - Girls with disabilities } \\
\text { less accepted when } \\
\text { they exhibit more } \\
\text { social problems. } \\
\text { - Girls with disabilities } \\
\text { more likely to be } \\
\text { accepted when girls' } \\
\text { attitudes towards } \\
\text { disabilities are } \\
\text { positive. }\end{array}$ & $\begin{array}{l}\text { result in social } \\
\text { behavior issues? } \\
\text { - Small sample of } \\
\text { students with ADHD } \\
\text { and ASD limits } \\
\text { generalizability. } \\
\text { - Limited number of } \\
\text { independent } \\
\text { variables examined. }\end{array}$ \\
\hline $\begin{array}{l}\text { O'Rourke and } \\
\text { Houghton } \\
\text { [43] (2008) } \\
\text { (Australia) }\end{array}$ & $\begin{array}{l}\text { Examine the } \\
\text { perceptions of } \\
\text { secondary school } \\
\text { students with } \\
\text { mild disabilities } \\
\text { to the academic } \\
\text { and social } \\
\text { support } \\
\text { mechanisms } \\
\text { implemented in } \\
\text { regular } \\
\text { classrooms. }\end{array}$ & $\begin{array}{l}\text { Inclusive } \\
\text { secondary } \\
\text { schools } \\
\text { (regular and } \\
\text { education } \\
\text { support } \\
\text { environments } \\
\text { in schools) } \\
\text { Mean age: } 15 \\
\text { yrs } \\
\text { Years 8-12 }\end{array}$ & Questionnaire & $\begin{array}{l}\mathrm{n}=60 \\
\text { students with } \\
\text { mild } \\
\text { disabilities } \\
(35 \%)\end{array}$ & $\begin{array}{l}\text { Mild } \\
\text { disabilities } \\
\text { (diagnoses } \\
\text { not } \\
\text { specified) }\end{array}$ & $\begin{array}{l}\text { - Instructional } \\
\text { mechanisms/good } \\
\text { teaching practice (clear } \\
\text { teaching, making } \\
\text { subject interesting, } \\
\text { having a friendly } \\
\text { teacher) perceived with } \\
\text { positive academic } \\
\text { outcomes. } \\
\text { - Teacher being } \\
\text { friendly/well-liked by } \\
\text { student perceived with } \\
\text { positive social } \\
\text { outcomes. } \\
\text { - One-on-one support } \\
\text { seen as most helpful } \\
\text { for academic outcomes } \\
\text { but perceived as } \\
\text { obstacle to making } \\
\text { friends. } \\
\text { - Sitting with } \\
\text { peers/working on } \\
\text { projects together seen } \\
\text { as helpful with } \\
\text { academic and social }\end{array}$ & $\begin{array}{l}\text { - Students' responses } \\
\text { limited to support } \\
\text { mechanisms } \\
\text { measured by the } \\
\text { scale (Student } \\
\text { Perceptions of } \\
\text { Classroom Support). }\end{array}$ \\
\hline
\end{tabular}




\begin{tabular}{|c|c|c|c|c|c|c|c|}
\hline & & & & & & $\begin{array}{l}\text { outcomes (e.g., making } \\
\text { friends). }\end{array}$ & \\
\hline $\begin{array}{l}\text { Petry [44] } \\
(2018) \\
\text { Belgium }\end{array}$ & $\begin{array}{l}\text { Explore the } \\
\text { relationships } \\
\text { between } \\
\text { attitudes towards } \\
\text { peers with a } \\
\text { disability at the } \\
\text { level of the class } \\
\text { \& peer } \\
\text { acceptance, } \\
\text { friendships, \& } \\
\text { peer interactions } \\
\text { of students with } \\
\text { ASD or sensory } \\
\text { and/or motor } \\
\text { limitations } \\
\text { (FYS). }\end{array}$ & 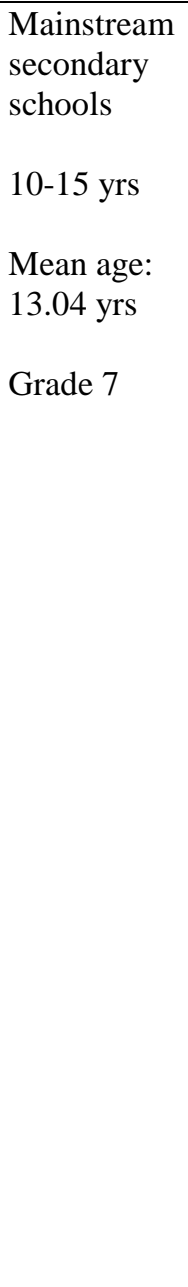 & $\begin{array}{l}\text { Questionnaire } \\
\text { Sociometric } \\
\text { nominations \& } \\
\text { ratings }\end{array}$ & $\begin{array}{l}\mathrm{n}=2013 \\
(45.4 \%) \\
1866 \text { typically } \\
\text { developing } \\
\text { peers; } \\
86 \text { children } \\
\text { with ASD; } \\
61 \text { children } \\
\text { with FYS }\end{array}$ & $\begin{array}{l}\text { ASD, } \\
\text { FYS }\end{array}$ & $\begin{array}{l}\text { - Students with ASD \& } \\
\text { students with FYS } \\
\text { were less accepted by } \\
\text { peers, had fewer } \\
\text { reciprocal friendships, } \\
\text { \& were less engaged in } \\
\text { peer interactions than } \\
\text { typically developing } \\
\text { peers. } \\
\text { - The average class } \\
\text { attitude of typically } \\
\text { developing peers } \\
\text { towards peers with a } \\
\text { disability was neutral. } \\
\text { However, in some } \\
\text { classes, negative } \\
\text { attitudes were } \\
\text { displayed. } \\
\text { - Class attitudes were } \\
\text { lower (more negative } \\
\text { attitudes) when the } \\
\text { inclusion involved } \\
\text { students with ASD } \\
\text { than when students } \\
\text { with FYS were } \\
\text { involved. } \\
\text { - The relationship } \\
\text { between class attitudes } \\
\text { \& peer acceptance, } \\
\text { friendships, \& peer } \\
\text { interactions of students } \\
\text { with ASD \& FYS was }\end{array}$ & $\begin{array}{l}\text { - As this was an } \\
\text { exploratory study of } \\
\text { the moderating role } \\
\text { of disability type on } \\
\text { the relationship } \\
\text { between class } \\
\text { attitudes \& social } \\
\text { participation, more } \\
\text { research is needed } \\
\text { - This study focused } \\
\text { on } 3 \text { of the } 4 \text { key } \\
\text { aspects of social } \\
\text { participation. } \\
\text { Research on all } 4 \\
\text { aspects is needed. }\end{array}$ \\
\hline
\end{tabular}




\begin{tabular}{|c|c|c|c|c|c|c|c|}
\hline & & & & & & $\begin{array}{l}\text { moderated by type of } \\
\text { disability. }\end{array}$ & \\
\hline $\begin{array}{l}\text { Pijl et al. [40] } \\
\text { (2008) } \\
\text { (Norway) }\end{array}$ & $\begin{array}{l}\text { Describe the } \\
\text { social position of } \\
\text { students with } \\
\text { and without } \\
\text { special needs in } \\
\text { regular } \\
\text { education } \\
\text { settings in } \\
\text { Norway. }\end{array}$ & $\begin{array}{l}\text { Primary and } \\
\text { lower } \\
\text { secondary } \\
\text { schools in } \\
\text { Norway (full } \\
\text { inclusion } \\
\text { policy) } \\
9-10 \text { yrs \& } \\
12-13 \text { yrs } \\
\text { Grade } 4 \text { \& } 7\end{array}$ & $\begin{array}{l}\text { Sociometric } \\
\text { techniques } \\
\text { based on peer } \\
\text { nomination }\end{array}$ & $\begin{array}{l}\mathrm{n}=989 \\
910 \text { students } \\
\text { without } \\
\text { special } \\
\text { education } \\
\text { needs (SEN); } \\
79 \text { students } \\
\text { with SEN } \\
491 \text { fourth } \\
\text { graders; } \\
498 \text { seventh } \\
\text { graders }\end{array}$ & SEN & $\begin{array}{l}\text { - Students with special } \\
\text { needs less accepted, } \\
\text { fewer friendships, and } \\
\text { participate less often as } \\
\text { members of a } \\
\text { subgroup. } \\
\text { - Between } 15-20 \% \text { of } \\
\text { students with special } \\
\text { needs socially } \\
\text { excluded. } \\
\text { - Rates of isolation } \\
\text { higher for students } \\
\text { with behavioral } \\
\text { (52.2\%) and } \\
\text { communication } \\
\text { (58.3\%) problems vs. } \\
\text { sensorial/motor } \\
\text { impairment (28.5\%). }\end{array}$ & $\begin{array}{l}\text { - Students' answers } \\
\text { can be subject to } \\
\text { social desirability } \\
\text { bias. } \\
\text { - Nonrandom sample } \\
\text { limits } \\
\text { generalizability. }\end{array}$ \\
\hline $\begin{array}{l}\text { Shokoohi- } \\
\text { Yekta and } \\
\text { Hendrickson } \\
\text { [45] (2010) } \\
\text { (USA and } \\
\text { Iran) }\end{array}$ & $\begin{array}{l}\text { Examine } \\
\text { opinions of } \\
\text { American and } \\
\text { Iranian high } \\
\text { school students } \\
\text { re: friendships } \\
\text { with peers with } \\
\text { severe } \\
\text { disabilities. }\end{array}$ & 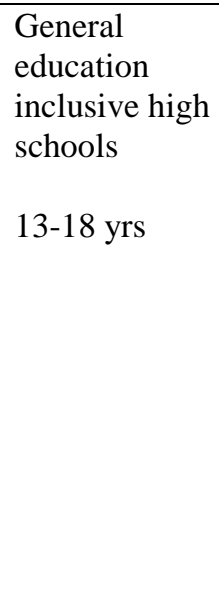 & Questionnaire & $\begin{array}{l}\mathrm{n}=945 \\
656 \text { American } \\
\text { students } \\
(51.5 \%) ; \\
289 \text { Iranian } \\
\text { students } \\
(51.2 \%)\end{array}$ & $\begin{array}{l}\text { Severe } \\
\text { disabilities } \\
\text { focus of } \\
\text { questionnair } \\
\text { e }\end{array}$ & $\begin{array}{l}\text { - Americans felt more } \\
\text { strongly than Iranians } \\
\text { that friendships with } \\
\text { students with severe } \\
\text { disability not easy. } \\
\text { - Regular class for the } \\
\text { entire day seen as most } \\
\text { likely facilitator of } \\
\text { friendships for both } \\
\text { student groups. } \\
\text { - Having students work } \\
\text { together \& arranging } \\
\text { social activities where } \\
\text { all can participate top } \\
\text { strategies to promote }\end{array}$ & $\begin{array}{l}\text { - Nonrandom sample } \\
\text { of students limits } \\
\text { generalizability. } \\
\text { - Self-report bias } \\
\text { inherent in survey. }\end{array}$ \\
\hline
\end{tabular}




\begin{tabular}{|c|c|c|c|c|c|c|c|}
\hline & & & & & & $\begin{array}{l}\text { inclusion for both } \\
\text { groups. }\end{array}$ & \\
\hline $\begin{array}{l}\text { Tuersley- } \\
\text { Dixon and } \\
\text { Frederickson } \\
\text { [41] (2016) } \\
\text { (England) }\end{array}$ & $\begin{array}{l}\text { Examined } \\
\text { whether social } \\
\text { acceptance of } \\
\text { students with } \\
\text { complex needs } \\
\text { by peers varies } \\
\text { with visibility of } \\
\text { severity of } \\
\text { disability, and } \\
\text { how successful } \\
\text { social inclusion } \\
\text { is of students } \\
\text { with complex } \\
\text { needs. }\end{array}$ & $\begin{array}{l}\text { Mainstream } \\
\text { primary } \\
\text { schools } \\
5-11 \text { yrs } \\
\text { Mean age: } \\
8.92 \text { yrs }\end{array}$ & Questionnaire & $\begin{array}{l}\mathrm{n}=548 \\
20 \text { children } \\
\text { with complex } \\
\text { needs }(40 \%) ; \\
528 \text { typically } \\
\text { developing } \\
\text { classmates }\end{array}$ & $\begin{array}{l}\text { SEN (20); } \\
\text { ASD (1), } \\
\text { cerebral } \\
\text { palsy (3), } \\
\text { Down's } \\
\text { syndrome } \\
\text { (8), } \\
\text { epilepsy (1), } \\
\text { Rett } \\
\text { syndrome } \\
\text { (1) }\end{array}$ & $\begin{array}{l}\text { - Number of mutual } \\
\text { friendships with } \\
\text { classmates, social } \\
\text { status, acceptance, and } \\
\text { rejection of children } \\
\text { with complex care } \\
\text { needs similar to } \\
\text { typically developing } \\
\text { peers. } \\
\text { - Social acceptance of } \\
\text { children with complex } \\
\text { needs by typically } \\
\text { developing peers } \\
\text { higher in the presence } \\
\text { of visible than non- } \\
\text { visible disability. } \\
\text { - Social acceptance } \\
\text { higher for children } \\
\text { with more severe } \\
\text { difficulties. }\end{array}$ & $\begin{array}{l}\text { - Small sample size } \\
\text { limits } \\
\text { generalizability. } \\
\text { - Participants received } \\
\text { high level and } \\
\text { quality of support } \\
\text { from outreach } \\
\text { program. Whether } \\
\text { similar findings with } \\
\text { less support is } \\
\text { unknown. }\end{array}$ \\
\hline $\begin{array}{l}\text { Wendelborg } \\
\text { and Kvello } \\
{[42](2010)} \\
\text { (Norway) }\end{array}$ & $\begin{array}{l}\text { Explore the } \\
\text { relationship } \\
\text { between } \\
\text { educational } \\
\text { arrangements, } \\
\text { social } \\
\text { participation } \\
\text { during leisure } \\
\text { time, and } \\
\text { perceived social } \\
\text { acceptance and } \\
\text { peer intimacy } \\
\text { among disabled } \\
\text { children. }\end{array}$ & 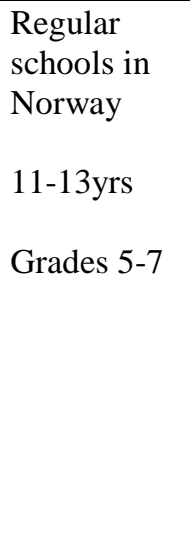 & $\begin{array}{l}\text { Questionnaires } \\
\text { completed by } \\
\text { parents and } \\
\text { children who } \\
\text { were able to } \\
\text { do so }\end{array}$ & $\begin{array}{l}\mathrm{n}=85 \\
\text { students with } \\
\text { disabilities } \\
(43.5 \%)\end{array}$ & $\begin{array}{l}\text { Physical } \\
\text { disability, } \\
\text { intellectual } \\
\text { disability, } \\
\text { other } \\
\text { disabilities }\end{array}$ & $\begin{array}{l}\text { - Social participation in } \\
\text { leisure time has direct } \\
\text { effect on perceived } \\
\text { social acceptance and } \\
\text { peer intimacy. } \\
\text { - Type \& degree of } \\
\text { impairment \& hours of } \\
\text { special education have } \\
\text { indirect effects on } \\
\text { social participation in } \\
\text { leisure time through } \\
\text { classroom } \\
\text { participation. }\end{array}$ & $\begin{array}{l}\text { - Use of self-report } \\
\text { measures excludes } \\
\text { children with more } \\
\text { severe disabilities. } \\
\text { - Many children } \\
\text { completed } \\
\text { questionnaires with a } \\
\text { parent, which may } \\
\text { have influenced their } \\
\text { responses. }\end{array}$ \\
\hline
\end{tabular}




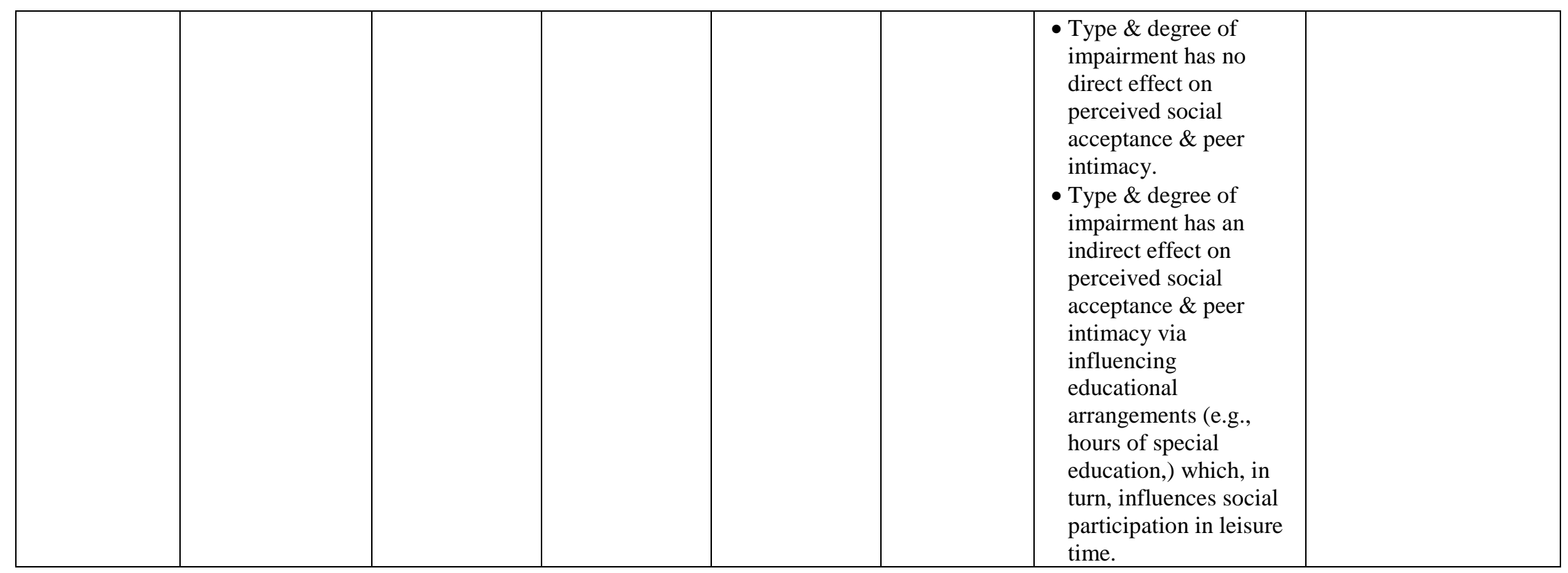


Table 2. Qualitative Studies Included in the Systematic Review

\begin{tabular}{|c|c|c|c|c|c|c|c|}
\hline $\begin{array}{c}\text { Author, } \\
\text { Year/ } \\
\text { Country }\end{array}$ & Purpose & $\begin{array}{l}\text { Setting, } \\
\text { Age and/or } \\
\text { Grade }\end{array}$ & $\begin{array}{c}\text { Data } \\
\text { Collection } \\
\text { Method }\end{array}$ & $\begin{array}{c}\text { Number } \\
\text { (\% Female) }\end{array}$ & Disability & Main Findings & Limitations \\
\hline $\begin{array}{l}\text { Anderson et } \\
\text { al. [70] } \\
\text { (2011) } \\
\text { (Australia) }\end{array}$ & $\begin{array}{l}\text { Examine } \\
\text { existing } \\
\text { friendships } \\
\text { between } \\
\text { typically } \\
\text { developing } \\
\text { children and } \\
\text { children with } \\
\text { disabilities and } \\
\text { use } \\
\text { augmentative } \\
\text { and alternative } \\
\text { communication } \\
\text { (AAC). }\end{array}$ & $\begin{array}{l}\text { Primary } \\
\text { school and } \\
\text { high school } \\
7-14 \text { yrs }\end{array}$ & Interviews & $\begin{array}{l}\mathrm{n}=6 \text { students } \\
\text { without } \\
\text { disabilities } \\
(50 \%)\end{array}$ & Cerebral palsy & $\begin{array}{l}\text { - Formation and } \\
\text { continued success of } \\
\text { friendships influenced } \\
\text { by: social values, } \\
\text { knowledge of and } \\
\text { attitudes to disability, } \\
\text { motivations } \\
\text { (rewards/benefits) for } \\
\text { friendship, personality } \\
\text { characteristics of } \\
\text { children with and } \\
\text { without disabilities in } \\
\text { the dyads. } \\
\text { - Having a friend with a } \\
\text { disability is different in } \\
\text { terms of learning, } \\
\text { roles, interactions, } \\
\text { shared time, helping. }\end{array}$ & $\begin{array}{l}\text { - Children who use } \\
\text { AAC were not } \\
\text { interviewed. }\end{array}$ \\
\hline $\begin{array}{l}\text { Asbjornslett } \\
\text { et al. [46] } \\
\text { (2012) } \\
\text { (Norway) }\end{array}$ & $\begin{array}{l}\text { Examine how } \\
\text { Norwegian } \\
\text { children with } \\
\text { physical } \\
\text { disabilities } \\
\text { experience } \\
\text { friendship } \\
\text { during the } \\
\text { transition } \\
\text { between } \\
\text { primary and } \\
\text { secondary } \\
\text { school. }\end{array}$ & 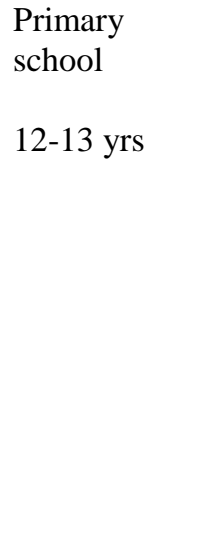 & $\begin{array}{l}\text { Life mode } \\
\text { Interviews }\end{array}$ & $\begin{array}{l}\mathrm{n}=15 \\
\text { children with } \\
\text { impairments } \\
(40 \%)\end{array}$ & $\begin{array}{l}\text { Physical } \\
\text { impairments } \\
\text { (14), } \\
\text { visual } \\
\text { impairment } \\
\text { (1) }\end{array}$ & $\begin{array}{l}\text { - Two themes: } \\
\text { (1) Different kinds of } \\
\text { friends: friends with } \\
\text { disabilities, friends } \\
\text { without disabilities, } \\
\text { technology-mediated } \\
\text { friendships; (2) } \\
\text { Qualities of } \\
\text { friendships: } \\
\text { understanding, } \\
\text { intimacy, trust, } \\
\text { mutuality and }\end{array}$ & $\begin{array}{l}\text { - Not all children } \\
\text { participated in } \\
\text { interviews at } \\
\text { multiple time points } \\
\text { during the transition } \\
\text { process } \\
\text { - Rigor of data } \\
\text { analysis process is } \\
\text { unclear }\end{array}$ \\
\hline
\end{tabular}




\begin{tabular}{|c|c|c|c|c|c|c|c|}
\hline & & & & & & $\begin{array}{l}\text { friendships with } \\
\text { children with and } \\
\text { without disabilities. }\end{array}$ & \\
\hline $\begin{array}{l}\text { Batorowicz et } \\
\text { al. [47] } \\
(2014) \\
\text { (Canada) }\end{array}$ & $\begin{array}{l}\text { Examine } \\
\text { perspective of } \\
\text { children who } \\
\text { use aided } \\
\text { communication } \\
\text { and their parents } \\
\text { on social } \\
\text { participation, } \\
\text { communicative } \\
\text { interactions, and } \\
\text { relationships. }\end{array}$ & $\begin{array}{l}\text { Community } \\
\text { (recruited } \\
\text { from } \\
\text { rehabilitation } \\
\text { centers) } \\
5-14 \text { yrs } \\
\text { Mean age: } \\
10.75 \text { yrs }\end{array}$ & Interviews & $\begin{array}{l}\mathrm{n}=16 \\
(75 \%) \\
8 \text { children } \\
\text { with } \\
\text { disabilities; } \\
8 \text { parents of } \\
\text { children in } \\
\text { study }\end{array}$ & $\begin{array}{l}\text { Cerebral palsy } \\
\text { (7), not } \\
\text { specified } \\
\text { (1) }\end{array}$ & $\begin{array}{l}\text { - Five themes: (1) } \\
\text { Communication } \\
\text { partners \& strategies } \\
\text { (2) Access to aided } \\
\text { communication } \\
\text { (3) Participation in } \\
\text { society } \\
\text { (4) Interaction } \\
\text { opportunities } \\
\text { (5) Social relationships }\end{array}$ & $\begin{array}{l}\text { - Majority of children } \\
\text { in segregated } \\
\text { classrooms. } \\
\text { - Although children } \\
\text { were asked about } \\
\text { their experiences, } \\
\text { they provided brief } \\
\text { answers. }\end{array}$ \\
\hline $\begin{array}{l}\text { Cook et al. } \\
{[48](2018)} \\
(\mathrm{UK})\end{array}$ & $\begin{array}{l}\text { Explore the } \\
\text { experiences of } \\
\text { learning, } \\
\text { friendships, and } \\
\text { bullying of girls } \\
\text { with autism. }\end{array}$ & 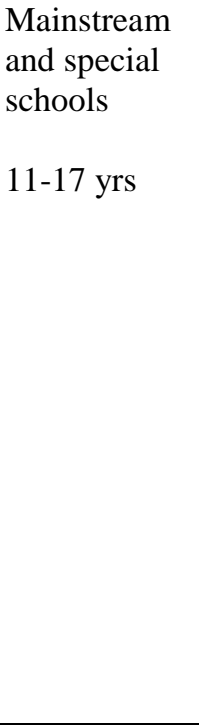 & $\begin{array}{l}\text { Semi- } \\
\text { structured } \\
\text { interviews }\end{array}$ & $\begin{array}{l}\mathrm{n}=22 \\
11 \text { children } \\
\text { with ASD } \\
(100 \%) ; \\
11 \text { parents } \\
(90.9 \%)\end{array}$ & ASD & $\begin{array}{l}\text { - Interviews revealed } \\
\text { themes relating to: (1) } \\
\text { motivation to have } \\
\text { friends, (2) challenges } \\
\text { they face, and (3) } \\
\text { masking their autism } \\
\text { to fit in which had both } \\
\text { positive (solution to } \\
\text { social difficulties) \& } \\
\text { negative consequences } \\
\text { (if led to } \\
\text { misdiagnosis). } \\
\text { - The girls were } \\
\text { motivated to have } \\
\text { friends but } \\
\text { encountered social } \\
\text { difficulties (e.g., social } \\
\text { isolation, bullying). }\end{array}$ & $\begin{array}{l}\text { All participants } \\
\text { could communicate } \\
\text { clearly. The findings } \\
\text { pertain to this group } \\
\text { and cannot be } \\
\text { transferred to others } \\
\text { with varying levels } \\
\text { of communication } \\
\text { skills. } \\
\text { The all-female child } \\
\text { sample did not allow } \\
\text { for comparison } \\
\text { across gender. }\end{array}$ \\
\hline $\begin{array}{l}\text { Correa-Torres } \\
\text { [49] (2008) } \\
\text { (USA) }\end{array}$ & $\begin{array}{l}\text { Study social } \\
\text { experiences of } \\
\text { students with } \\
\text { deaf-blindness, }\end{array}$ & $\begin{array}{l}\text { Inclusive } \\
\text { schools } \\
7-9 \text { yrs }\end{array}$ & $\begin{array}{l}\text { Interviews } \\
\text { Observations }\end{array}$ & $\begin{array}{l}\mathrm{n}=9 \\
3 \text { children } \\
\text { with }\end{array}$ & $\begin{array}{l}\text { Visual \& } \\
\text { hearing } \\
\text { disabilities, }\end{array}$ & $\begin{array}{l}\text { - Nature of social } \\
\text { experiences } \\
\text { - Strategies used by } \\
\text { adults to promote and }\end{array}$ & $\begin{array}{l}\text { - Teachers \& } \\
\text { paraprofessionals } \\
\text { perceived } \\
\text { educational setting }\end{array}$ \\
\hline
\end{tabular}




\begin{tabular}{|c|c|c|c|c|c|c|c|}
\hline & $\begin{array}{l}\text { their sighted } \\
\text { peers with no } \\
\text { hearing } \\
\text { impairment, and } \\
\text { adults. }\end{array}$ & $\mathrm{K}$ - Grade 4 & $\begin{array}{l}\text { Examination } \\
\text { of artifacts }\end{array}$ & $\begin{array}{l}\text { disabilities } \\
(33.3 \%) ; \\
3 \text { parents } \\
(100 \%) ; \\
4 \text { staff (e.g. } \\
\text { intervener; } \\
\text { para- } \\
\text { professional) } \\
\text { (100\%); } \\
4 \text { teachers } \\
(100 \%)\end{array}$ & $\begin{array}{l}\text { additional } \\
\text { disabilities }\end{array}$ & $\begin{array}{l}\text { facilitate interactions } \\
\text { and socialization } \\
\text { among deaf-blind } \\
\text { students and their } \\
\text { nondisabled peers. } \\
\text { - The benefits and } \\
\text { challenges of inclusion } \\
\text { - Reality of inclusion in } \\
\text { schools selected by } \\
\text { American }\end{array}$ & $\begin{array}{l}\text { as inclusive but } \\
\text { observations } \\
\text { revealed that deaf- } \\
\text { blind students were } \\
\text { more mainstreamed } \\
\text { than included in } \\
\text { school \& classroom } \\
\text { activities. } \\
\text { - Time for observation } \\
\text { was limited. } \\
\text { - Potential Hawthorne } \\
\text { effect. } \\
\text { - No intra- or inter- } \\
\text { observer agreement. }\end{array}$ \\
\hline $\begin{array}{l}\text { De Schauwer } \\
\text { et al. [50] } \\
\text { (2009) } \\
\text { (Belgium) }\end{array}$ & $\begin{array}{l}\text { Examine } \\
\text { disabled } \\
\text { children's } \\
\text { experience of } \\
\text { inclusive } \\
\text { education. }\end{array}$ & $\begin{array}{l}\begin{array}{l}\text { Mainstream } \\
\text { school }\end{array} \\
5-17 \mathrm{yrs}\end{array}$ & $\begin{array}{l}\text { Observations } \\
\text { Semi- } \\
\text { structured } \\
\text { interviews }\end{array}$ & $\begin{array}{l}\mathrm{n}=15 \\
\text { children with } \\
\text { disabilities } \\
(73.3 \%)\end{array}$ & $\begin{array}{l}\text { Down } \\
\text { syndrome (2), } \\
\text { cerebral palsy } \\
(6), \\
\text { motor } \\
\text { problems (2), } \\
\text { intellectual } \\
\text { disability (3), } \\
\text { intellectual } \\
\text { disability \& } \\
\text { ADHD (1), } \\
\text { Noonan } \\
\text { syndrome (1) }\end{array}$ & $\begin{array}{l}\text { Themes: (1) Just } \\
\text { another kid } \\
\text { (2) Capacities \& } \\
\text { disabilities } \\
\text { (3) Impairments \& } \\
\text { difficulties } \\
\text { (4) Belonging } \\
\text { (5) About school } \\
\text { (6) Social relationships } \\
\text { with other children \& } \\
\text { young people } \\
\text { (7) Help \& support in } \\
\text { the class \& at school }\end{array}$ & $\begin{array}{l}\text { - Strategies used to } \\
\text { interview children } \\
\text { unable to } \\
\text { communicate } \\
\text { verbally were not } \\
\text { clearly described; } \\
\text { possible influence of } \\
\text { parent or staff } \\
\text { member on these } \\
\text { children's responses }\end{array}$ \\
\hline $\begin{array}{l}\text { Dolva et al. } \\
\text { [51] (2010) } \\
\text { (Norway) }\end{array}$ & $\begin{array}{l}\text { Explore peer } \\
\text { interaction in } \\
\text { mainstream } \\
\text { classes that } \\
\text { included } \\
\text { students with } \\
\text { Down syndrome } \\
\text { and their peers }\end{array}$ & $\begin{array}{l}\text { Mainstream } \\
\text { Primary } \\
\text { schools } \\
10 \text { yrs }\end{array}$ & $\begin{array}{l}\begin{array}{l}\text { Field } \\
\text { observations }\end{array} \\
\text { Interviews }\end{array}$ & $\begin{array}{l}\mathrm{n}=6 \text { children } \\
\text { with Down's } \\
\text { syndrome } \\
(33.3 \%)\end{array}$ & $\begin{array}{l}\text { Down's } \\
\text { syndrome }\end{array}$ & $\begin{array}{l}\text { - Two main categories: } \\
\text { (1) Equal interaction } \\
\text { between students with } \\
\& \text { without Down } \\
\text { syndrome } \\
\text { (2) Unequal interaction } \\
\text { between students with }\end{array}$ & $\begin{array}{l}\text { - By focusing on } \\
\text { interactions that } \\
\text { occurred and } \\
\text { excluding initiations, } \\
\text { unsuccessful } \\
\text { attempts, and } \\
\text { solitary activity, } \\
\text { results may provide }\end{array}$ \\
\hline
\end{tabular}




\begin{tabular}{|c|c|c|c|c|c|c|c|}
\hline & $\begin{array}{l}\text { without } \\
\text { disabilities and } \\
\text { to identify } \\
\text { enabling } \\
\text { conditions. }\end{array}$ & & & & & $\begin{array}{l}\text { \& without Down } \\
\text { syndrome. } \\
\text { - Enabling conditions: } \\
\text { found necessary for } \\
\text { interactions to take } \\
\text { place: } \\
\text { (1) Students' shared } \\
\text { understanding of what } \\
\text { the activity entailed } \\
\text { (2) Activity is within } \\
\text { students' performance } \\
\text { range. } \\
\text { - Peers support in } \\
\text { interaction: Students } \\
\text { modified activities/ } \\
\text { tasks or their behavior } \\
\text { to include student with } \\
\text { Down syndrome. }\end{array}$ & $\begin{array}{l}\text { an inaccurate } \\
\text { portrayal of peer } \\
\text { interaction. }\end{array}$ \\
\hline $\begin{array}{l}\text { Faggo and } \\
\text { Webster [52] } \\
\text { (2017) } \\
\text { Australia }\end{array}$ & $\begin{array}{l}\text { Explore the } \\
\text { social } \\
\text { experiences } \\
\text { (relationships } \\
\text { with female } \\
\text { peers, } \\
\text { expectations \& } \\
\text { qualities of } \\
\text { social } \\
\text { interactions and } \\
\text { friendships) of } \\
\text { adolescent } \\
\text { females on the } \\
\text { autism } \\
\text { spectrum. }\end{array}$ & $\begin{array}{l}\text { Mainstream } \\
\text { secondary } \\
\text { school } \\
13-17 \text { yrs }\end{array}$ & $\begin{array}{l}\text { Semi- } \\
\text { structured } \\
\text { interviews }\end{array}$ & $\begin{array}{l}\mathrm{n}=7 \text { children } \\
\text { on the autism } \\
\text { spectrum } \\
(100 \%)\end{array}$ & $\begin{array}{l}\text { Asperger's } \\
\text { syndrome (4), } \\
\text { ASD (3) }\end{array}$ & $\begin{array}{l}\text { - Participants' } \\
\text { interviews revealed } 2 \\
\text { main themes: Social } \\
\text { interactions are } \\
\text { important and social } \\
\text { interactions are } \\
\text { difficult particularly } \\
\text { when involving groups } \\
\text { of peers. } \\
\text { - Participants consider } \\
\text { friendships with other } \\
\text { girls important and } \\
\text { rewarding. Although } \\
\text { they find socialization } \\
\text { to be difficult at times, } \\
\text { they seemed able to } \\
\text { manage their } \\
\text { challenges. }\end{array}$ & $\begin{array}{l}\text { - Data were not } \\
\text { sought from } \\
\text { participants' female } \\
\text { peers. Thus, it is not } \\
\text { possible to assess } \\
\text { whether participants } \\
\text { were involved in } \\
\text { true reciprocal } \\
\text { relationships. } \\
\text { - It cannot be } \\
\text { guaranteed that } \\
\text { participants' } \\
\text { responses were not } \\
\text { influenced by their } \\
\text { parents. }\end{array}$ \\
\hline
\end{tabular}




\begin{tabular}{|c|c|c|c|c|c|c|c|}
\hline & & & & & & $\begin{array}{l}\text { - Participants reported } \\
\text { uncertainty about the } \\
\text { expectations of others } \\
\text { for them. } \\
\text { - Trust, honesty, } \\
\text { reciprocity, \& support } \\
\text { in friendships were } \\
\text { valued by participants. }\end{array}$ & \\
\hline $\begin{array}{l}\text { Howard et al., } \\
\text { [53] (2006) } \\
\text { (USA) }\end{array}$ & $\begin{array}{l}\text { Explore } \\
\text { friendship } \\
\text { perceptions of } \\
\text { an adolescent } \\
\text { with Asperger } \\
\text { syndrome. }\end{array}$ & $\begin{array}{l}\text { Recruited } \\
\text { from } \\
\text { community } \\
\text { social skills } \\
\text { group for } \\
\text { adolescents } \\
\text { with ASD } \\
12 \text { yrs } \\
\text { Grade } 7\end{array}$ & $\begin{array}{l}\text { Semi- } \\
\text { structured } \\
\text { interviews } \\
\text { Photographs } \\
\text { taken by the } \\
\text { adolescent } \\
\text { Quality of Life } \\
\& \text { friendship } \\
\text { measures }\end{array}$ & $\begin{array}{l}\mathrm{n}=1 \text { child } \\
\text { with Asperger } \\
\text { syndrome } \\
(0 \%)\end{array}$ & $\begin{array}{l}\text { Asperger } \\
\text { syndrome }\end{array}$ & $\begin{array}{l}\text { - Three themes: } \\
\text { (1) Characteristics of a } \\
\text { friend } \\
\text { (2) Family } \\
\text { involvement in } \\
\text { facilitating \& } \\
\text { supporting friendships } \\
\text { (3) Enjoyment of } \\
\text { friendships \& interest } \\
\text { in maintaining them }\end{array}$ & $\begin{array}{l}\text { - Participant was } \\
\text { home schooled, } \\
\text { which may have } \\
\text { impacted friendship } \\
\text { patterns. } \\
\text { Data based on } \\
\text { interviews, not } \\
\text { actual observations. }\end{array}$ \\
\hline $\begin{array}{l}\text { Kalymon et } \\
\text { al. [71] } \\
\text { (2010) (USA) }\end{array}$ & $\begin{array}{l}\text { Examine factors } \\
\text { that contribute } \\
\text { to the } \\
\text { development of } \\
\text { positive peer } \\
\text { relationships } \\
\text { between middle- } \\
\text { school students } \\
\text { with and } \\
\text { without } \\
\text { disabilities. }\end{array}$ & $\begin{array}{l}\text { Mainstream } \\
\text { middle school } \\
13 \text { yrs } \\
\text { Grade } 7\end{array}$ & $\begin{array}{l}\text { Semi- } \\
\text { structured } \\
\text { interviews }\end{array}$ & $\begin{array}{l}\mathrm{n}=8 \text { typically } \\
\text { developing } \\
\text { children }(0 \%)\end{array}$ & $\begin{array}{l}\text { Disabilities } \\
\text { requiring } \\
\text { special } \\
\text { education } \\
\text { services }\end{array}$ & $\begin{array}{l}\text { - Five themes: } \\
\text { (1) Perceived } \\
\text { similarity in interests } \\
\text { \& ability } \\
\text { (2) Role of the } \\
\text { adolescent without } \\
\text { disabilities } \\
\text { (3) Amount of time } \\
\text { students with \& } \\
\text { without disability } \\
\text { spend together in \& } \\
\text { out of school } \\
\text { (4) Peer reactions } \\
\text { towards students with } \\
\text { disabilities }\end{array}$ & $\begin{array}{l}\text { - Findings are based } \\
\text { on perceptions of } \\
\text { boys without } \\
\text { disabilities. } \\
\text { - Participants } \\
\text { recruited from } \\
\text { school that was } \\
\text { exemplary in terms } \\
\text { of inclusion and } \\
\text { level of contact } \\
\text { between peers with } \\
\text { and without } \\
\text { disabilities. } \\
\text { - Restricted range of } \\
\text { classmates with } \\
\text { disabilities discussed } \\
\text { by participants }\end{array}$ \\
\hline
\end{tabular}




\begin{tabular}{|c|c|c|c|c|c|c|c|}
\hline & & & & & & $\begin{array}{l}\text { (5) Adults' behavior } \\
\text { towards students with } \\
\text { disabilities. } \\
\text { - Participants noted } \\
\text { elementary school } \\
\text { context facilitated } \\
\text { friendships more than } \\
\text { middle school. } \\
\text { - Amount of time spent } \\
\text { with peers with } \\
\text { disabilities outside of } \\
\text { school was minimal. }\end{array}$ & $\begin{array}{l}\text { (participants limited } \\
\text { their discussion to } \\
\text { classmates with } \\
\text { significant physical } \\
\text { or intellectual } \\
\text { disabilities or severe } \\
\text { behavioral } \\
\text { challenges. }\end{array}$ \\
\hline $\begin{array}{l}\text { Kamenopoulo } \\
\text { u [54] (2012) } \\
\text { (United } \\
\text { Kingdom) }\end{array}$ & $\begin{array}{l}\text { Explore social } \\
\text { inclusion and } \\
\text { participation of } \\
4 \text { deafblind } \\
\text { students }\end{array}$ & $\begin{array}{l}\text { Mainstream } \\
\text { secondary } \\
\text { educational } \\
\text { setting }\end{array}$ & $\begin{array}{l}\text { Semi- } \\
\text { structured } \\
\text { interviews } \\
\text { Observations } \\
\text { of peer } \\
\text { interactions } \\
\text { Semi- } \\
\text { structured } \\
\text { questionnaire }\end{array}$ & $\begin{array}{l}\mathrm{n}=16 \\
4 \text { students } \\
\text { with deaf- } \\
\text { blindness, } \\
8 \text { teachers, } \\
4 \text { parents }\end{array}$ & $\begin{array}{l}\text { Deaf- } \\
\text { blindness }\end{array}$ & $\begin{array}{l}\text { Themes: } \\
\text { - Issues with Social } \\
\text { Inclusion: (1) Lack of } \\
\text { mutuality of } \\
\text { relationships; (2) } \\
\text { Bullying; (3) } \\
\text { Communication } \\
\text { breakdowns; (4) } \\
\text { Leisure time spent } \\
\text { alone or family. } \\
\text { - Barriers to Social } \\
\text { Inclusion: (1) Person- } \\
\text { related: Visual \& } \\
\text { hearing needs, } \\
\text { Difficulties with } \\
\text { independent } \\
\text { movement; (2) } \\
\text { Context-related: Poor } \\
\text { social skills, Strategies } \\
\text { used to meet learning } \\
\text { needs \& facilitate } \\
\text { access \& greater } \\
\text { inclusion, Unhelpful }\end{array}$ & $\begin{array}{l}\text { - Findings may not be } \\
\text { relevant to other } \\
\text { deaf-blind students, } \\
\text { as all participants } \\
\text { were oral } \\
\text { communicators and } \\
\text { able to cope well in } \\
\text { mainstream } \\
\text { educational settings } \\
\text { - Interviews with } \\
\text { students did not } \\
\text { elicit rich narratives, } \\
\text { possibly due to need } \\
\text { to adapt interview } \\
\text { techniques more } \\
\text { specifically for each } \\
\text { participants' needs } \\
\text { and lack of repeated } \\
\text { interview sessions } \\
\text { - Potential for } \\
\text { presence of adults in } \\
\text { interview setting to } \\
\text { influence students' } \\
\text { responses }\end{array}$ \\
\hline
\end{tabular}




\begin{tabular}{|c|c|c|c|c|c|c|c|}
\hline & & & & & & $\begin{array}{l}\text { working relationships } \\
\text { at school. } \\
\text { - Facilitators of Social } \\
\text { Inclusion: (1) } \\
\text { Awareness of } \\
\text { deaf/blindness \& } \\
\text { implications for } \\
\text { communication; (2) } \\
\text { Good working } \\
\text { relationships atschool; } \\
\text { (3) Preparation of } \\
\text { school context prior to } \\
\text { mainstream placement }\end{array}$ & \\
\hline $\begin{array}{l}\text { Kayama and } \\
\text { Haight [55] } \\
\text { (2013) } \\
\text { (Japan) }\end{array}$ & $\begin{array}{l}\text { How Japanese } \\
\text { children with } \\
\text { developmental } \\
\text { disabilities } \\
\text { experience the } \\
\text { new formal } \\
\text { system of } \\
\text { special } \\
\text { education \& } \\
\text { how they } \\
\text { actively create } \\
\text { peer } \\
\text { relationships. }\end{array}$ & $\begin{array}{l}\text { Elementary } \\
\text { school in } \\
\text { which special } \\
\text { education } \\
\text { services for } \\
\text { children with } \\
\text { disabilities } \\
\text { were offered } \\
7,8, \& 11 \mathrm{yrs}\end{array}$ & $\begin{array}{l}\text { Participant } \\
\text { observation } \\
\text { Individual } \\
\text { interviews } \\
\text { School records } \\
\text { review }\end{array}$ & $\begin{array}{l}\mathrm{n}=3 \text { children } \\
\text { with } \\
\text { disabilities } \\
(0 \%)\end{array}$ & $\begin{array}{l}\text { Asperger's } \\
(2), \\
\text { learning } \\
\text { disability (1) }\end{array}$ & $\begin{array}{l}\text { - Educators emphasized } \\
\text { importance of peer } \\
\text { groups in socializing \& } \\
\text { educating all children } \\
\text { - Three ways children } \\
\text { with developmental } \\
\text { disabilities connected } \\
\text { with peers: (1) } \\
\text { Learning to self- } \\
\text { regulate contact with } \\
\text { peers; (2) Connecting } \\
\text { with peers through } \\
\text { social interests; (3) } \\
\text { Connecting with peers } \\
\text { through play. }\end{array}$ & $\begin{array}{l}\text { - Limited pool of } \\
\text { potential participants } \\
\text { due to parents' } \\
\text { sensitivity to stigma } \\
\text { of disability }\end{array}$ \\
\hline $\begin{array}{l}\text { MacArthur et } \\
\text { al. [56] } \\
\text { (2007) } \\
\text { (New } \\
\text { Zealand) }\end{array}$ & $\begin{array}{l}\text { Explore the } \\
\text { school } \\
\text { experiences of } \\
\text { children with } \\
\text { disabilities and } \\
\text { their agency in a } \\
\text { social world } \\
\text { where } \\
\text { "difference" }\end{array}$ & $\begin{array}{l}\text { Mainstream } \\
\text { primary and } \\
\text { secondary } \\
\text { schools } \\
11-14 \text { yrs }\end{array}$ & $\begin{array}{l}\text { Observations } \\
\text { Semi- } \\
\text { structured } \\
\text { interviews }\end{array}$ & $\begin{array}{l}\mathrm{n}=7 \text { children } \\
\text { with } \\
\text { disabilities } \\
\text { Parents/caregi } \\
\text { vers, teachers, } \\
\text { school } \\
\text { principals }\end{array}$ & $\begin{array}{l}\text { Physical, } \\
\text { intellectual, } \\
\text { and autism } \\
\text { related } \\
\text { impairments }\end{array}$ & $\begin{array}{l}\text { - Children's experiences } \\
\text { of difference } \\
\text { - Disabled children as } \\
\text { social actors at school } \\
\text { - Children's agency \& } \\
\text { bullying } \\
\text { - Children's agency \& } \\
\text { teaching and learning }\end{array}$ & $\begin{array}{l}\text { - No description of } \\
\text { data analysis } \\
\text { methods are } \\
\text { provided }\end{array}$ \\
\hline
\end{tabular}




\begin{tabular}{|c|c|c|c|c|c|c|c|}
\hline & $\begin{array}{l}\text { was experienced } \\
\text { negatively. }\end{array}$ & & & & & $\begin{array}{l}\text { - Agency and children's } \\
\text { behavior }\end{array}$ & \\
\hline $\begin{array}{l}\text { McMaugh } \\
\text { [57] (2011) } \\
\text { (Australia) }\end{array}$ & $\begin{array}{l}\text { Explores the } \\
\text { educational and } \\
\text { social } \\
\text { experiences of } \\
\text { children with } \\
\text { physical } \\
\text { disability or } \\
\text { chronic illness } \\
\text { as they } \\
\text { transition to } \\
\text { junior high } \\
\text { school. }\end{array}$ & $\begin{array}{l}\text { Mainstream } \\
\text { primary } \\
\text { schools; } \\
\text { mainstream } \\
\text { and partially } \\
\text { segregated } \\
\text { secondary } \\
\text { schools } \\
\text { Mean age: } \\
12.4 \text { yrs } \\
\text { Three cycles: } \\
\text { Late Year } 6 \\
\text { Early Year } 7 \\
\text { Late Year } 7\end{array}$ & $\begin{array}{l}\text { Semi- } \\
\text { structured } \\
\text { interviews }\end{array}$ & $\begin{array}{l}\mathrm{n}=24 \\
\text { children with } \\
\text { disabilities }\end{array}$ & $\begin{array}{l}\text { Cerebral palsy } \\
(8), \\
\text { cystic fibrosis } \\
(4), \\
\text { traumatic } \\
\text { brain injury } \\
(3), \\
\text { spina bifida } \\
\text { (2), other } \\
\text { chronic } \\
\text { physical } \\
\text { illness or } \\
\text { physical } \\
\text { disability (7) }\end{array}$ & $\begin{array}{l}\text { - Three themes: (1) } \\
\text { en/counters of } \\
\text { disablement in peer } \\
\text { relationships; (2) } \\
\text { encounters of } \\
\text { disablement in the } \\
\text { sense of self; and the } \\
\text { role of school } \\
\text { structures; (3) practices } \\
\text { in shaping the } \\
\text { transitional experience. }\end{array}$ & $\begin{array}{l}\text { - Some participants } \\
\text { transitioned from } \\
\text { mainstream primary } \\
\text { schools to partially } \\
\text { segregated } \\
\text { secondary schools } \\
\text { while others } \\
\text { transitioned to } \\
\text { mainstream } \\
\text { secondary schools; } \\
\text { the experiences of } \\
\text { students in these two } \\
\text { different } \\
\text { environments were } \\
\text { not clearly } \\
\text { delineated } \\
\text { - Data analysis } \\
\text { procedures were not } \\
\text { explicated }\end{array}$ \\
\hline $\begin{array}{l}\text { Morrison and } \\
\text { Burgman [58] } \\
\text { (2009) } \\
\text { (Australia) }\end{array}$ & $\begin{array}{l}\text { Explore the } \\
\text { experiences of } \\
\text { friendship for } \\
\text { children with } \\
\text { disabilities who } \\
\text { attend } \\
\text { mainstream } \\
\text { Australian } \\
\text { schools. }\end{array}$ & $\begin{array}{l}\text { Mainstream } \\
\text { urban (8) and } \\
\text { rural (2) } \\
\text { primary } \\
\text { schools } \\
8-10 \text { yrs }\end{array}$ & $\begin{array}{l}\text { Semi- } \\
\text { structured } \\
\text { interviews }\end{array}$ & $\begin{array}{l}\mathrm{n}=10 \\
\text { children with } \\
\text { disabilities } \\
(40 \%)\end{array}$ & $\begin{array}{l}\text { Visual } \\
\text { impairment } \\
(3), \\
\text { hearing loss } \\
(1), \\
\text { ADHD (1), } \\
\text { spastic } \\
\text { quadriplegia } \\
(1), \\
\text { spina bifida } \\
(1), \\
\text { post } \\
\text { meningococ- } \\
\text { cal disease (1), } \\
\text { acquired brain }\end{array}$ & $\begin{array}{l}\text { - Five themes: } \\
\text { (1) Self-identify } \\
\text { (2) Meaning of } \\
\text { friendship } \\
\text { (3) Classroom } \\
\text { experiences } \\
\text { (4) Playing together } \\
\text { (5) Longing for } \\
\text { friendship }\end{array}$ & $\begin{array}{l}\text { - Redundancy of data } \\
\text { was not achieved, as } \\
\text { original sample did } \\
\text { not focus solely on } \\
\text { this topic. } \\
\text { - Findings may not be } \\
\text { applicable to other } \\
\text { educational contexts. }\end{array}$ \\
\hline
\end{tabular}




\begin{tabular}{|c|c|c|c|c|c|c|c|}
\hline & & & & & $\begin{array}{l}\text { injury (1), } \\
\text { spastic } \\
\text { diplegia (1) }\end{array}$ & & \\
\hline $\begin{array}{l}\text { Mortier et al. } \\
\text { [66] (2011) } \\
\text { (Belgium) }\end{array}$ & $\begin{array}{l}\text { Gain an } \\
\text { understanding } \\
\text { of the effects } \\
\text { supports can } \\
\text { have from the } \\
\text { perspectives of } \\
6 \text { children with } \\
\text { special needs } \\
\text { and their peers. }\end{array}$ & $\begin{array}{l}\text { Primary and } \\
\text { Secondary } \\
\text { inclusive } \\
\text { schools } \\
9-18 \text { yrs }\end{array}$ & $\begin{array}{l}\text { Semi- } \\
\text { structured } \\
\text { interviews } \\
\text { Focus groups }\end{array}$ & $\begin{array}{l}\mathrm{n}=25 \\
6 \text { children } \\
\text { with a } \\
\text { disability } \\
(66.7 \%) ; \\
19 \text { typically } \\
\text { developing } \\
\text { peers }\end{array}$ & Not specified & $\begin{array}{l}\text { - Children mainly } \\
\text { identified positive } \\
\text { effects of supports in } \\
\text { removing restrictions } \\
\text { in activity. } \\
\text { - Themes: (1) } \\
\text { Impairment effects: } \\
\text { areas children were } \\
\text { struggling due to } \\
\text { receiving supports to } \\
\text { reduce impairment } \\
\text { effects; (2) Disability } \\
\text { effects: Barriers in } \\
\text { doing and being due to } \\
\text { disability. } \\
\text { - Children with a } \\
\text { disability \& peers were } \\
\text { positive about school } \\
\text { supports. } \\
\text { - Majority of supports } \\
\text { aimed at dealing with } \\
\text { barriers to activity }\end{array}$ & $\begin{array}{l}\text { Typically } \\
\text { developing peers' } \\
\text { responses in focus } \\
\text { groups may have } \\
\text { been influenced by } \\
\text { the presence of their } \\
\text { classmate with } \\
\text { disabilities }\end{array}$ \\
\hline $\begin{array}{l}\text { Murphy et al. } \\
\text { [59] (2017) } \\
\text { UK }\end{array}$ & $\begin{array}{l}\text { Explore } \\
\text { relationships as } \\
\text { described by } \\
\text { adolescents with } \\
\text { Autism } \\
\text { Spectrum } \\
\text { Disorder (ASD) } \\
\& \text { the } \\
\text { development of } \\
\text { successful } \\
\text { interpersonal } \\
\text { relationships for }\end{array}$ & $\begin{array}{l}\text { Community } \\
13-16 \text { yrs }\end{array}$ & $\begin{array}{l}\text { Semi- } \\
\text { structured } \\
\text { interviews }\end{array}$ & $\begin{array}{l}\mathrm{n}=8 \\
\text { adolescents } \\
\text { with ASD } \\
(25 \%)\end{array}$ & $\begin{array}{l}\text { Asperger's } \\
\text { syndrome (6), } \\
\text { ASD (1), } \\
\text { Autism (1) }\end{array}$ & $\begin{array}{l}\text { Four main themes } \\
\text { were found: (1) } \\
\text { relationships as a } \\
\text { source of support, (2) } \\
\text { perceptions of } \\
\text { similarity \& } \\
\text { difference, (3) valued } \\
\text { qualities in self \& } \\
\text { others, \& (4) } \\
\text { development \& } \\
\text { maintenance of } \\
\text { relationships }\end{array}$ & $\begin{array}{l}\text { - The disconnected } \\
\text { nature of the } \\
\text { constructs generated } \\
\text { by participants made } \\
\text { it challenging to } \\
\text { discern how one } \\
\text { construct linked with } \\
\text { another. } \\
\text { - While laddering may } \\
\text { be a useful way of } \\
\text { exploring how } \\
\text { constructs might }\end{array}$ \\
\hline
\end{tabular}




\begin{tabular}{|c|c|c|c|c|c|c|c|}
\hline & $\begin{array}{l}\text { these } \\
\text { individuals. }\end{array}$ & & & & & $\begin{array}{l}\text { - Participants viewed } \\
\text { relationships in terms } \\
\text { of the support \& } \\
\text { protection they } \\
\text { afforded. They } \\
\text { perceived similarities } \\
\& \text { differences between } \\
\text { themselves \& the } \\
\text { important people in } \\
\text { their lives. They } \\
\text { acknowledged the } \\
\text { development of } \\
\text { successful } \\
\text { relationships to be an } \\
\text { active process, } \\
\text { supported by humour } \\
\text { \& shared interests. } \\
\text { - Participants valued } \\
\text { intelligence, humour, } \\
\text { respect \& trust within } \\
\text { relationships } \\
\text { - PCT was found to be a } \\
\text { useful approach to } \\
\text { elicit rich qualitative } \\
\text { data }\end{array}$ & $\begin{array}{l}\text { connect, with this } \\
\text { population it may } \\
\text { not be relied upon to } \\
\text { generate a hierarchy. }\end{array}$ \\
\hline $\begin{array}{l}\text { Naraian [60] } \\
\text { (2011) (USA) }\end{array}$ & $\begin{array}{l}\text { Explore the } \\
\text { relations } \\
\text { between a child } \\
\text { with disability } \\
\& \text { his peer to } \\
\text { understand the } \\
\text { scope \& quality } \\
\text { of teacher } \\
\text { mediation that } \\
\text { can facilitate } \\
\text { peer }\end{array}$ & $\begin{array}{l}\text { Inclusive } \\
\text { elementary } \\
\text { setting } \\
\text { Grade } 1\end{array}$ & $\begin{array}{l}\text { Participant } \\
\text { observation of } \\
\text { peer } \\
\text { interactions in } \\
\text { the classroom } \\
\text { Open-ended } \\
\text { interviews } \\
\text { Field notes }\end{array}$ & $\begin{array}{l}\mathrm{n}=15 \\
1 \text { student with } \\
\text { disabilities } \\
(0 \%), \\
1 \text { typically } \\
\text { developing } \\
\text { peer (100\%), } \\
3 \text { teachers, } \\
2 \text { therapists, }\end{array}$ & $\begin{array}{l}\text { Visually } \\
\text { impaired, non- } \\
\text { verbal } \\
\text { wheelchair } \\
\text { user with } \\
\text { significant } \\
\text { develop- } \\
\text { mental delays } \\
\text { not using any } \\
\text { formal means }\end{array}$ & $\begin{array}{l}\text { - Themes: (1) Knowing } \\
\text { Harry: A cause of } \\
\text { celebration; (2) } \\
\text { Growing pains: } \\
\text { Changing relations or } \\
\text { changing perceptions; } \\
\text { (3) The discursive } \\
\text { context of Andrea's } \\
\text { relations with Harry; } \\
\text { (4) Disentangling } \\
\text { threads. }\end{array}$ & $\begin{array}{l}\text { - Majority of data } \\
\text { collected from adult } \\
\text { perspectives as } \\
\text { interviews were not } \\
\text { conducted with child } \\
\text { with disabilities or } \\
\text { typically developing } \\
\text { peer }\end{array}$ \\
\hline
\end{tabular}




\begin{tabular}{|c|c|c|c|c|c|c|c|}
\hline & $\begin{array}{l}\text { engagement } \\
\text { with children } \\
\text { with disabilities. }\end{array}$ & & & $\begin{array}{l}1 \\
\text { paraprofession } \\
\text { al, } \\
1 \text { principal, } 6 \\
\text { parents } \\
(100 \%)\end{array}$ & $\begin{array}{l}\text { of communi- } \\
\text { cation }\end{array}$ & & \\
\hline $\begin{array}{l}\text { Nowicki and } \\
\text { Brown [72] } \\
\text { (2013) } \\
\text { (Canada) }\end{array}$ & $\begin{array}{l}\text { Explore how } \\
\text { junior level } \\
\text { elementary } \\
\text { students socially } \\
\text { include } \\
\text { classmates with } \\
\text { learning or } \\
\text { intellectual } \\
\text { disabilities. }\end{array}$ & $\begin{array}{l}\begin{array}{l}\text { Inclusive } \\
\text { elementary } \\
\text { schools }\end{array} \\
9-12 \text { yrs } \\
\text { Mean age: } \\
10.42 \text { yrs } \\
\text { Grades 5-6 }\end{array}$ & Interviews & $\begin{array}{l}\mathrm{n}=36 \\
\text { typically } \\
\text { developing } \\
\text { children } \\
(44.4 \%)\end{array}$ & $\begin{array}{l}\text { Learning } \\
\text { difficulties }\end{array}$ & $\begin{array}{l}\text { - Eighty strategies } \\
\text { categorized into } 7 \\
\text { themes: (1) Involve the } \\
\text { teacher; (2) } \\
\text { Instructional strategies } \\
\text { that can be used by } \\
\text { children; (3) Being } \\
\text { supportive by helping, } \\
\text { encouraging \& giving } \\
\text { advice; (4) Focusing } \\
\text { on similarities, not } \\
\text { differences; (5) } \\
\text { Modeling appropriate } \\
\text { social behaviors \& } \\
\text { intervening in non- } \\
\text { appropriate social } \\
\text { behaviors; (6) } \\
\text { Structured social } \\
\text { interactions that are } \\
\text { inclusive; (7) Special } \\
\text { programs \& activities } \\
\text { that are non-inclusive. }\end{array}$ & $\begin{array}{l}\text { - Since participants } \\
\text { were recruited from } \\
\text { a school that is fully } \\
\text { inclusive and has } \\
\text { been for some time, } \\
\text { results may not be } \\
\text { transferable to } \\
\text { students in other } \\
\text { educational } \\
\text { environments } \\
\text { - Possible self- } \\
\text { selection bias in } \\
\text { sampling }\end{array}$ \\
\hline $\begin{array}{l}\text { O'Hagan and } \\
\text { Hebron [61] } \\
\text { (2017) } \\
\text { UK }\end{array}$ & $\begin{array}{l}\text { Explore the } \\
\text { meaning \& } \\
\text { nature of } \\
\text { friendship } \\
\text { among } \\
\text { adolescents with } \\
\text { Autism } \\
\text { Spectrum }\end{array}$ & $\begin{array}{l}\begin{array}{l}\text { Mainstream } \\
\text { secondary } \\
\text { school }\end{array} \\
13-15 \text { yrs } \\
\text { Year } 8 \text { \& } 10\end{array}$ & $\begin{array}{l}\text { Semi- } \\
\text { structured } \\
\text { interviews }\end{array}$ & $\begin{array}{l}\mathrm{n}=9 \\
3 \text { high } \\
\text { functioning } \\
\text { adolescents } \\
\text { with ASC } \\
(0 \%), \\
3 \text { parents, } \\
(66.6 \%),\end{array}$ & $\begin{array}{l}\text { Asperger } \\
\text { syndrome (2), } \\
\text { ASD (1) }\end{array}$ & $\begin{array}{l}\text { - All students desired } \\
\text { friendships \& reported } \\
\text { experiencing } \\
\text { loneliness. } \\
\text { - Friendships centered } \\
\text { on common interests } \\
\text { or structured activities } \\
\text { (e.g., computer } \\
\text { games). }\end{array}$ & $\begin{array}{l}\text { - Sampling bias- } \\
\text { students were } \\
\text { recruited by the } \\
\text { school's special } \\
\text { education needs } \\
\text { coordinator. } \\
\text { - The all-male sample } \\
\text { limits transferability } \\
\text { to girls with ASC }\end{array}$ \\
\hline
\end{tabular}




\begin{tabular}{|c|c|c|c|c|c|c|c|}
\hline & $\begin{array}{l}\text { Conditions } \\
\text { (ASC). }\end{array}$ & & & $\begin{array}{l}3 \text { staff } \\
\text { members (1 } \\
\text { support } \\
\text { worker, 1 } \\
\text { teaching } \\
\text { assistant, head } \\
\text { of ASC } \\
\text { resource } \\
\text { provision) }\end{array}$ & & $\begin{array}{l}\text { - Individual and } \\
\text { contextual influences } \\
\text { on friendship } \\
\text { development } \\
\text { included: level of } \\
\text { maturity, } \\
\text { understanding of social } \\
\text { rules, school } \\
\text { environment, \& peer } \\
\text { acceptance. }\end{array}$ & $\begin{array}{l}\text { - All participants had } \\
\text { high functioning } \\
\text { ASC. Studying the } \\
\text { friendship } \\
\text { development among } \\
\text { young people from } \\
\text { across the ASC } \\
\text { spectrum is } \\
\text { warranted. }\end{array}$ \\
\hline $\begin{array}{l}\text { Parry [62] } \\
\text { (2014) } \\
\text { (England) }\end{array}$ & $\begin{array}{l}\text { Examine how } \\
\text { social } \\
\text { connections and } \\
\text { friendships } \\
\text { between two } \\
\text { children labelled } \\
\text { with special } \\
\text { education needs } \\
\text { and their peers } \\
\text { develop }\end{array}$ & $\begin{array}{l}\text { Inclusive } \\
\text { children's } \\
\text { center and } \\
\text { nursery school } \\
3.5-4 \text { yrs }\end{array}$ & $\begin{array}{l}\text { Observations } \\
\text { Photographs } \\
\text { of observed } \\
\text { interactions } \\
\text { Semi- } \\
\text { structured } \\
\text { interviews } \\
\text { with staff }\end{array}$ & $\begin{array}{l}\mathrm{n}=9 \\
2 \text { children } \\
\text { with special } \\
\text { educational } \\
\text { needs }(0 \%), \\
7 \text { staff } \\
\text { members }\end{array}$ & $\begin{array}{l}\text { Hearing } \\
\text { impairment } \\
\text { (1), } \\
\text { speech } \\
\text { impairment } \\
\text { (1) }\end{array}$ & $\begin{array}{l}\text { - Themes: (1) Recurrent } \\
\text { playmates (playing } \\
\text { more regularly with } \\
\text { certain peers); (2) } \\
\text { Seeking help \& } \\
\text { engagement from } \\
\text { familiar playmates; (3) } \\
\text { Interaction with other } \\
\text { children (attempts to } \\
\text { play with other } \\
\text { children); (4) Other } \\
\text { children initiating } \\
\text { (other children } \\
\text { approached children } \\
\text { with disabilities). } \\
\text { - Adult support: children } \\
\text { studied often } \\
\text { interacted with peers } \\
\text { without adult support. } \\
\text { Other times, adults } \\
\text { were initiating \&/or } \\
\text { facilitating, peer } \\
\text { interactions. }\end{array}$ & $\begin{array}{l}\text { - Majority of data } \\
\text { collected from adult } \\
\text { perspectives (i.e. } \\
\text { researcher narratives } \\
\text { of play interactions, } \\
\text { researcher-generated } \\
\text { photographs, } \\
\text { interviews with } \\
\text { adults about } \\
\text { children's } \\
\text { friendships) }\end{array}$ \\
\hline $\begin{array}{l}\text { Parry [67] } \\
\text { (2015) } \\
\text { (England) }\end{array}$ & $\begin{array}{l}\text { Examine social } \\
\text { interactions } \\
\text { between } \\
\text { children with }\end{array}$ & $\begin{array}{l}\text { Inclusive } \\
\text { preschool } \\
3-4 \text { yrs }\end{array}$ & $\begin{array}{l}\text { Play } \\
\text { observations } \\
\text { Photographs }\end{array}$ & $\begin{array}{l}\mathrm{n}=6 \text { children } \\
\text { with special } \\
\text { educational } \\
\text { needs }\end{array}$ & $\begin{array}{l}\text { Down } \\
\text { syndrome (1), } \\
\text { language and } \\
\text { commun- }\end{array}$ & $\begin{array}{l}\text { Themes: } \\
\text { (1) Using toys \& } \\
\text { activities to initiate }\end{array}$ & $\begin{array}{l}\text { - Majority of data } \\
\text { collected from adult } \\
\text { perspectives (i.e. } \\
\text { researcher narratives }\end{array}$ \\
\hline
\end{tabular}




\begin{tabular}{|c|c|c|c|c|c|c|c|}
\hline & $\begin{array}{l}\text { special } \\
\text { educational } \\
\text { needs and their } \\
\text { peers within } \\
\text { their preschool. }\end{array}$ & & $\begin{array}{l}\text { Interviews } \\
\text { with staff }\end{array}$ & $\begin{array}{l}\text { Peers, } \\
\text { staff members }\end{array}$ & $\begin{array}{l}\text { ication } \\
\text { difficulties (2), } \\
\text { general } \\
\text { learning } \\
\text { difficulties (1), } \\
\text { Social } \\
\text { commun- } \\
\text { ication } \\
\text { difficulties (2) }\end{array}$ & $\begin{array}{l}\text { play \& social contact } \\
\text { (2) Using routines to } \\
\text { engage other children; } \\
\text { (3) Keeping control of } \\
\text { exchanges (prolonged } \\
\text { \& reciprocal play was } \\
\text { the result if the focus } \\
\text { of the child with } \\
\text { disability was } \\
\text { followed); (4) Social } \\
\text { exchanges seldom } \\
\text { involved recurrent } \\
\text { playmates; (5) } \\
\text { Sophistication of play } \\
\text { or communication } \\
\text { skills did not have } \\
\text { influence on choice of } \\
\text { potential playmates. } \\
\text { - Factors influencing } \\
\text { choice of playmates: } \\
\text { similar play interests \& } \\
\text { personalities. }\end{array}$ & $\begin{array}{l}\text { of play interactions, } \\
\text { researcher-generated } \\
\text { photographs, } \\
\text { interviews with } \\
\text { adults about } \\
\text { children's } \\
\text { friendships) }\end{array}$ \\
\hline $\begin{array}{l}\text { Seymour et } \\
\text { al. [68] } \\
(2009) \\
\text { (Canada) }\end{array}$ & $\begin{array}{l}\text { Investigate } \\
\text { friendship in } \\
\text { inclusive } \\
\text { physical } \\
\text { education from } \\
\text { the perspective } \\
\text { of students with } \\
\text { and without } \\
\text { physical } \\
\text { disabilities. }\end{array}$ & $\begin{array}{l}\text { Reversely } \\
\text { integrated } \\
\text { primary } \\
\text { school (school } \\
\text { was originally } \\
\text { for students } \\
\text { with physical } \\
\text { disabilities but } \\
\text { now also } \\
\text { includes } \\
\text { typically }\end{array}$ & $\begin{array}{l}\text { Semi- } \\
\text { structured } \\
\text { open-ended } \\
\text { interviews }\end{array}$ & $\begin{array}{l}\mathrm{n}=16 \\
8 \text { students } \\
\text { with physical } \\
\text { disabilities } \\
(63 \%) \\
8 \text { students } \\
\text { without } \\
\text { disabilities } \\
(100 \%)\end{array}$ & $\begin{array}{l}\text { Diaplegia (2) } \\
\text { hemiplegia } \\
\text { (1), } \\
\text { neuromus- } \\
\text { cular disease } \\
\text { (2), } \\
\text { Quadriplegia } \\
\text { (3) }\end{array}$ & $\begin{array}{l}\text { - Four themes: (1) } \\
\text { Development of } \\
\text { friendship; (2) Best } \\
\text { friend; (3) Preferred } \\
\text { physical activities \& } \\
\text { outcomes; (4) Dealing } \\
\text { with disability. }\end{array}$ & $\begin{array}{l}\text { - Due to this school's } \\
\text { reversely integrated } \\
\text { nature, results from } \\
\text { this study may not } \\
\text { be transferable to } \\
\text { schools using other } \\
\text { integration/inclusion } \\
\text { programs } \\
\text { - Gender comparisons } \\
\text { could not be made as } \\
\text { there were only } 3 \\
\text { males in the sample. }\end{array}$ \\
\hline
\end{tabular}




\begin{tabular}{|c|c|c|c|c|c|c|c|}
\hline & & $\begin{array}{l}\begin{array}{l}\text { developing } \\
\text { children) }\end{array} \\
9-12 \text { yrs } \\
\text { Grades 4-6 }\end{array}$ & & & & & \\
\hline $\begin{array}{l}\text { Spencer- } \\
\text { Cavaliere and } \\
\text { Watkinson } \\
\text { [63] (2010) } \\
\text { (Canada) }\end{array}$ & $\begin{array}{l}\text { Explore the } \\
\text { perspectives and } \\
\text { perceptions of } \\
\text { children with } \\
\text { disabilities } \\
\text { regarding } \\
\text { inclusion in } \\
\text { physical activity } \\
\text { (e.g., sports, } \\
\text { games, and } \\
\text { play) }\end{array}$ & $\begin{array}{l}\text { Community } \\
\text { (two sports } \\
\text { and activity } \\
\text { programs } \\
\text { outside the } \\
\text { school system) } \\
\text { 8-12yrs } \\
\text { Mean age: } \\
10.42 \text { yrs } \\
\text { Grades 3-6 }\end{array}$ & $\begin{array}{l}\text { Semi- } \\
\text { structured } \\
\text { interviews } \\
\text { Reflexive field } \\
\text { notes }\end{array}$ & $\begin{array}{l}\mathrm{n}=11 \\
\text { children with } \\
\text { disabilities } \\
(18 \%)\end{array}$ & $\begin{array}{l}\text { Cerebral palsy } \\
\text { (5), } \\
\text { fine and gross } \\
\text { motor delays } \\
\text { (1), } \\
\text { developmental } \\
\text { coordination } \\
\text { disorder (1), } \\
\text { muscular } \\
\text { dystrophy (1), } \\
\text { nemaline } \\
\text { myopathy (1), } \\
\text { brachial } \\
\text { plexus injury } \\
\text { (1), } \\
\text { severe asthma } \\
\text { (1) }\end{array}$ & $\begin{array}{l}\text { - Three themes } \\
\text { regarding children's } \\
\text { perceptions of what } \\
\text { inclusion is: (1) } \\
\text { Gaining entry to play; } \\
\text { (2) Feeling like a } \\
\text { legitimate participant; } \\
\text { (3) Having friends. } \\
\text { - All themes associated } \\
\text { with feeling included } \\
\text { in sports, games, \& } \\
\text { play. }\end{array}$ & $\begin{array}{l}\text { - Nearly half of } \\
\text { participants had } \\
\text { cerebral palsy, } \\
\text { possibly contributing } \\
\text { to shared } \\
\text { experiences } \\
\text { - Gender comparisons } \\
\text { could not be made as } \\
\text { there were only } 2 \\
\text { females in the } \\
\text { sample }\end{array}$ \\
\hline $\begin{array}{l}\text { Spratling et } \\
\text { al. [64] } \\
\text { (2012) } \\
\text { (USA) }\end{array}$ & $\begin{array}{l}\text { Explore the } \\
\text { school age } \\
\text { child's } \\
\text { perspective } \\
\text { about living } \\
\text { with a } \\
\text { tracheostomy. }\end{array}$ & $\begin{array}{l}\text { Pulmonary } \\
\text { clinic in the } \\
\text { community } \\
7-11 \text { yrs } \\
\text { Mean age: } 8 \\
\text { yrs }\end{array}$ & $\begin{array}{l}\text { Interview } \\
\text { Field notes } \\
\text { and reflective } \\
\text { journal }\end{array}$ & $\begin{array}{l}\mathrm{n}=5 \text { school- } \\
\text { age children } \\
\text { with a } \\
\text { tracheostomy } \\
(20 \%)\end{array}$ & Tracheostomy & $\begin{array}{l}\text { - Three themes: (1) I'm } \\
\text { the only one; (2) } \\
\text { Friends are helpful; (3) } \\
\text { Just tell them. }\end{array}$ & $\begin{array}{l}\text { - Data saturation not } \\
\text { fully determined } \\
\text { - Redundancy in data } \\
\text { did occur. } \\
\text { - Primary investigator } \\
\text { knew study } \\
\text { participants \& } \\
\text { families; may have } \\
\text { influenced } \\
\text { responses, } \\
\text { recruitment, \& trust } \\
\text { of participants. } \\
\text { - One participant } \\
\text { decannulated prior to }\end{array}$ \\
\hline
\end{tabular}




\begin{tabular}{|c|c|c|c|c|c|c|c|}
\hline & & & & & & & $\begin{array}{l}\text { interview; child's } \\
\text { views may have } \\
\text { differed from other } \\
\text { children. } \\
\text { - Presence of parents } \\
\text { in the interview may } \\
\text { have influenced } \\
\text { children's responses. }\end{array}$ \\
\hline $\begin{array}{l}\text { Sumiya et al. } \\
\text { [65] (2018) } \\
\text { Japan }\end{array}$ & $\begin{array}{l}\text { Explore the } \\
\text { experiences of } \\
\text { adolescents with } \\
\text { autism spectrum } \\
\text { disorders of } \\
\text { anxiety and } \\
\text { loneliness in } \\
\text { developing } \\
\text { and maintaining } \\
\text { friendships at } \\
\text { school }\end{array}$ & $\begin{array}{l}\text { Private } \\
\text { remedial } \\
\text { centers, } \\
\text { college-based } \\
\text { remedial } \\
\text { teaching } \\
\text { centers, and } \\
\text { special } \\
\text { education } \\
\text { classes } \\
10-15 \text { yrs } \\
\end{array}$ & $\begin{array}{l}\text { Semi- } \\
\text { structured } \\
\text { interviews }\end{array}$ & $\begin{array}{l}\mathrm{n}=11 \text { high } \\
\text { functioning } \\
\text { adolescents } \\
\text { with autism } \\
\text { spectrum } \\
\text { disorders } \\
(27 \%)\end{array}$ & $\begin{array}{l}\text { Autism } \\
\text { disorder (2), } \\
\text { Asperger's } \\
\text { disorder (7), } \\
\text { Pervasive } \\
\text { development } \\
\text { disorder (2) }\end{array}$ & $\begin{array}{l}\text { Four themes: (1) Social } \\
\text { motivation; (2) } \\
\text { loneliness; (3) anxiety; } \\
\text { and (4) distress. }\end{array}$ & $\begin{array}{l}\text { Use of outdated } \\
\text { DSM criteria to } \\
\text { confirm diagnosis. }\end{array}$ \\
\hline $\begin{array}{l}\text { Ytterhus [69] } \\
\text { (2012) } \\
\text { (Norway) }\end{array}$ & $\begin{array}{l}\text { Studied } \\
\text { informal } \\
\text { interaction rules } \\
\text { negotiated/ } \\
\text { practiced by } \\
\text { children which } \\
\text { led to social } \\
\text { inclusion and } \\
\text { exclusion. }\end{array}$ & $\begin{array}{l}\begin{array}{l}\text { Nursery } \\
\text { schools, } \\
\text { primary, and } \\
\text { junior high } \\
\text { schools that } \\
\text { promote social } \\
\text { integration }\end{array} \\
3 \text { cycles: } \\
3-7 \text { yrs } \\
9-12 \text { yrs } \\
13-16 \text { yrs }\end{array}$ & 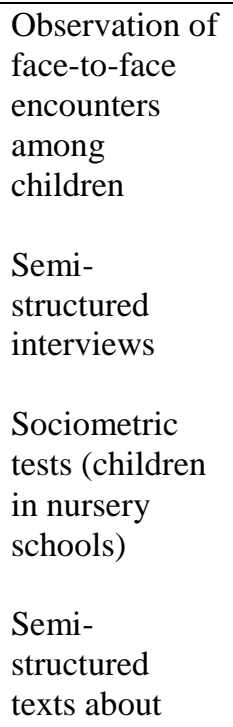 & $\begin{array}{l}3 \text { cycles: } \\
\mathrm{n}=56 \\
\text { children; } \\
47 \text { without } \\
\text { disabilities; } 9 \\
\text { with } \\
\text { disabilities } \\
(56 \%) \\
\mathrm{n}=100 \\
\text { children; } \\
93 \text { without } \\
\text { disabilities; } \\
7 \text { with } \\
\text { disabilities } \\
(57 \%)\end{array}$ & Not specified & $\begin{array}{l}\text { Informal social } \\
\text { interaction rules } \\
\text { emerged: } \\
\text { - Prohibiting rules (tell } \\
\text { children what not to } \\
\text { do): (1) Physically } \\
\text { harm peers; (2) } \\
\text { Express wrong } \\
\text { feelings; (3) Lose face; } \\
\text { (4) Disturb/destroy } \\
\text { other children's } \\
\text { activities; (5) Become } \\
\text { dirty/sticky. } \\
\text { - Mandating rules (tell } \\
\text { children what they } \\
\text { have to do to be } \\
\text { included): You must } \\
\text { be: (1) Good enough; }\end{array}$ & $\begin{array}{l}\text { - Findings may not be } \\
\text { transferable to } \\
\text { students in other } \\
\text { educational } \\
\text { environments, as this } \\
\text { study took place in a } \\
\text { school system that } \\
\text { was nearly fully } \\
\text { inclusive }\end{array}$ \\
\hline
\end{tabular}


Author accepted manuscript: Disability and Rehabilitation, $17^{\text {th }}$ December 2018

\begin{tabular}{|l|l|l|l|l|l|}
\hline & & friendship, & $\mathrm{n}=120$ & & (2) Similar enough; (3) \\
Status congruent. \\
children; \\
\end{tabular}


Table 3. Mixed Methods Studies Included in the Systematic Review

\begin{tabular}{|c|c|c|c|c|c|c|c|}
\hline $\begin{array}{c}\text { Author, } \\
\text { Year/ } \\
\text { Country }\end{array}$ & Purpose & $\begin{array}{l}\text { Setting, } \\
\text { Age and/or } \\
\text { Grade }\end{array}$ & $\begin{array}{c}\text { Data } \\
\text { Collection } \\
\text { Method }\end{array}$ & $\begin{array}{l}\text { Number } \\
\text { (\% Female) }\end{array}$ & Disability & Main Findings & Limitations \\
\hline $\begin{array}{l}\text { Avramidis } \\
\text { [78] (2013) } \\
\text { (England) }\end{array}$ & $\begin{array}{l}\text { Examine: (1) } \\
\text { self-concept of } \\
\text { students with } \\
\text { special } \\
\text { education needs } \\
\text { (SEN); (2) } \\
\text { sociometric } \\
\text { status of } \\
\text { students with } \\
\text { SEN within } \\
\text { social network } \\
\text { of their class; } \\
\text { (3) social } \\
\text { participation of } \\
\text { students w SEN } \\
\text { in peer groups. }\end{array}$ & $\begin{array}{l}\text { Mainstream } \\
\text { primary } \\
\text { schools } \\
\text { Years } 5 \& 6\end{array}$ & $\begin{array}{l}\begin{array}{l}\text { Self-report } \\
\text { questionnaire }\end{array} \\
\text { Sociometric } \\
\text { technique \& } \\
\text { indices of } \\
\text { participation } \\
\text { (e.g., friend } \\
\text { nominations) } \\
\text { Semi- } \\
\text { structured } \\
\text { interviews } \\
\text { with school } \\
\text { professionals }\end{array}$ & $\begin{array}{l}\mathrm{n}=593 \\
101 \text { students } \\
\text { with disability } \\
(53 \%), \\
465 \text { non-SEN } \\
\text { students } \\
(56 \%), \\
27 \\
\text { professionals } \\
\text { (teachers of } \\
\text { participating } \\
\text { classes, } \\
\text { teachers from } \\
\text { resource units, } \\
\& \text { SEN } \\
\text { coordinators) }\end{array}$ & $\begin{array}{l}\text { Cognitive \& } \\
\text { learning (82), } \\
\text { Behavioural, } \\
\text { emotional \& } \\
\text { social } \\
\text { development } \\
\text { (13), } \\
\text { Physical \& } \\
\text { sensory needs } \\
\text { (6) }\end{array}$ & $\begin{array}{l}\text { - Type and severity of } \\
\text { SEN did not affect } \\
\text { children's self-concept. } \\
\text { - Compared to non-SEN } \\
\text { peers, students with } \\
\text { SEN: (1) Received } \\
\text { fewer nominations \& } \\
\text { had fewer friendships; } \\
\text { (2) More likely to hold } \\
\text { ‘low' sociometric } \\
\text { status; (3) Equally } \\
\text { likely to be members } \\
\text { of a social group } \\
\text { - Type of SEN affected } \\
\text { no. of nominations } \\
\text { received. } \\
\text { - Teachers noted non- } \\
\text { SEN peers showed } \\
\text { empathy, } \\
\text { protectiveness \& } \\
\text { support towards } \\
\text { students with SEN. }\end{array}$ & $\begin{array}{l}\text { - Some types of } \\
\text { special education } \\
\text { needs were not } \\
\text { represented in the } \\
\text { sample. } \\
\text { - Sociometric } \\
\text { technique used (e.g., } \\
\text { peer nomination) } \\
\text { does not provide } \\
\text { information } \\
\text { regarding strength } \\
\text { and quality of } \\
\text { relationships. }\end{array}$ \\
\hline $\begin{array}{l}\text { Calder et al. } \\
\text { [79] (2013) } \\
\text { (United } \\
\text { Kingdom) }\end{array}$ & $\begin{array}{l}\text { Examine the } \\
\text { extent and } \\
\text { nature of } \\
\text { friendships for } \\
\text { children with } \\
\text { autism from } \\
\text { their perspective } \\
\text { and from those } \\
\text { of their mothers, }\end{array}$ & $\begin{array}{l}\begin{array}{l}\text { Mainstream } \\
\text { primary } \\
\text { schools }\end{array} \\
9-11 \text { yrs } \\
\text { Grades } 5 \& 6\end{array}$ & $\begin{array}{l}\text { Questionnaires } \\
\text { Vignettes } \\
\text { Observations } \\
\text { Semi- } \\
\text { structured } \\
\text { interviews }\end{array}$ & $\begin{array}{l}\mathrm{n}=279 \\
12 \text { children } \\
\text { with a } \\
\text { disability } \\
(33 \%), \\
11 \text { typically } \\
\text { developing } \\
\text { peers }(45 \%),\end{array}$ & Autism & $\begin{array}{l}\text { - Children with autism } \\
\text { rated their best } \\
\text { friendships as lower in } \\
\text { affective dimensions. } \\
\text { - Friendship groups } \\
\text { among children with } \\
\text { autism varied from } 1 \\
\text { to } 10 \text { children. }\end{array}$ & $\begin{array}{l}\text { - Small sample limits } \\
\text { generalizability. }\end{array}$ \\
\hline
\end{tabular}




\begin{tabular}{|c|c|c|c|c|c|c|c|}
\hline & $\begin{array}{l}\text { teachers, and } \\
\text { classroom peers. }\end{array}$ & & $\begin{array}{l}\text { Social } \\
\text { network } \\
\text { nominations }\end{array}$ & $\begin{array}{l}237 \text { classroom } \\
\text { peers, } \\
11 \text { parents } \\
(100 \%) \\
8 \text { teachers }\end{array}$ & & $\begin{array}{l}\text { - Most children with } \\
\text { autism (9/12) engaged } \\
\text { in social play with } \\
\text { peers. } \\
\text { - Themes - children with } \\
\text { autism: (1) Their } \\
\text { perceived role of } \\
\text { friendship; (2) The } \\
\text { challenges of } \\
\text { friendship. } \\
\text { - Themes - parents: (1) } \\
\text { Acknowledging } \\
\text { differences in } \\
\text { friendships; (2) Role of } \\
\text { schools in providing } \\
\text { support; (3) Parental } \\
\text { role in children's } \\
\text { friendships. } \\
\text { - Themes - teachers: (1) } \\
\text { Nature of friendships; } \\
\text { (2) Rules \& roles } \\
\text { within peer } \\
\text { interactions; (3) Role } \\
\text { of school staff in } \\
\text { supporting children's } \\
\text { friendships. } \\
\end{array}$ & \\
\hline $\begin{array}{l}\text { Chamberlain } \\
\text { et al. [80] } \\
\text { (2007) } \\
\text { (USA) }\end{array}$ & $\begin{array}{l}\text { Explore } \\
\text { involvement of } \\
\text { children with } \\
\text { autism in typical } \\
\text { classrooms. }\end{array}$ & $\begin{array}{l}\begin{array}{l}\text { General } \\
\text { education } \\
\text { classrooms }\end{array} \\
\text { Grade 2-5 }\end{array}$ & $\begin{array}{l}\begin{array}{l}\text { Social } \\
\text { network } \\
\text { nominations }\end{array} \\
\begin{array}{l}\text { Self-report } \\
\text { questionnaires }\end{array} \\
\text { Participant } \\
\text { observation }\end{array}$ & $\begin{array}{l}\mathrm{n}=398 \\
381 \text { students } \\
\text { without autism } \\
(53 \%), \\
17 \text { students } \\
\text { with disability } \\
(17.6 \%)\end{array}$ & $\begin{array}{l}\text { High - } \\
\text { functioning } \\
\text { autism or } \\
\text { Asperger's } \\
\text { syndrome }\end{array}$ & $\begin{array}{l}\text { Compared to matched } \\
\text { peer groups, children } \\
\text { with autism: (1) More } \\
\text { likely to have network } \\
\text { connections with girls; } \\
\text { (2) Less involved in } \\
\text { classroom social } \\
\text { structure; (3) Reported } \\
\text { spending less time } \\
\text { with their best friends } \\
\text { in class; (4) }\end{array}$ & $\begin{array}{l}\text { - Majority of } \\
\text { participants came } \\
\text { from upper middle- } \\
\text { class schools. } \\
\text { - The fact that only } \\
\text { children who had } \\
\text { permission from their } \\
\text { parents were enrolled } \\
\text { in the study (some } \\
\text { parents felt the } \\
\text { subject of friendships }\end{array}$ \\
\hline
\end{tabular}




\begin{tabular}{|c|c|c|c|c|c|c|c|}
\hline & & & $\begin{array}{l}\text { Analysis of } \\
\text { information } \\
\text { paragraphs } \\
\text { provided by } \\
\text { parents \& } \\
\text { transcribed } \\
\text { conversations } \\
\text { with parents } \\
\text { regarding } \\
\text { results }\end{array}$ & & & $\begin{array}{l}\text { Experienced less } \\
\text { reciprocity of } \\
\text { friendship; (5) } \\
\text { Received lower peer } \\
\text { acceptance scores; (6) } \\
\text { Did not report greater } \\
\text { loneliness. } \\
\text { - Themes: Importance of } \\
\text { parent \& teacher } \\
\text { supports for enhancing } \\
\text { children's social } \\
\text { integration \& peer } \\
\text { support. }\end{array}$ & $\begin{array}{l}\text { was too painful) may } \\
\text { have tilted results } \\
\text { towards the positive. }\end{array}$ \\
\hline $\begin{array}{l}\text { Dewey and } \\
\text { Volkovinskai } \\
\text { a [83] (2018) } \\
\text { Canada }\end{array}$ & $\begin{array}{l}\text { Examine health- } \\
\text { related quality } \\
\text { of life (HRQoL) } \\
\text { and peer } \\
\text { relationships in } \\
\text { adolescents with } \\
\text { developmental } \\
\text { coordination } \\
\text { disorder (DCD) } \\
\text { \& ADHD. }\end{array}$ & $\begin{array}{l}\begin{array}{l}\text { Community } \\
\text { (existing } \\
\text { cohort study) }\end{array} \\
11-18 \mathrm{yrs}\end{array}$ & $\begin{array}{l}\text { Questionnaire } \\
\text { Semi- } \\
\text { structured } \\
\text { interviews }\end{array}$ & $\begin{array}{l}\mathrm{n}=44 \\
\text { adolescents } \\
28 \text { adolescents } \\
\text { with } \\
\text { disabilities } \\
(28.6 \%) ; \\
16 \text { typically } \\
\text { developing } \\
\text { peers }(62.5 \%)\end{array}$ & $\begin{array}{l}\text { DCD (9), } \\
\text { ADHD (9), } \\
\text { DCD \& } \\
\text { ADHD (10) }\end{array}$ & $\begin{array}{l}\text { - Adolescents with co- } \\
\text { occurring DCD \& } \\
\text { ADHD had lower } \\
\text { HRQoL than } \\
\text { adolescents with DCD } \\
\text { and typically } \\
\text { developing peers. } \\
\text { - Adolescents with both } \\
\text { DCD \& ADHD } \\
\text { reported higher } \\
\text { victimization } \\
\text { compared to } \\
\text { adolescents with DCD } \\
\text { and typically } \\
\text { developing peers. } \\
\text { - Adolescents with } \\
\text { DCD, ADHD, and co- } \\
\text { occurring DCD \& } \\
\text { ADHD did not see } \\
\text { themselves as popular } \\
\text { and described } \\
\text { themselves as } \\
\text { "oddballs" or "weird". }\end{array}$ & $\begin{array}{l}\text { - Small sample size of } \\
\text { each of the } \\
\text { participant groups } \\
\text { limits } \\
\text { generalizability. } \\
\text { - The instrument used } \\
\text { to measure peer } \\
\text { relationships (The } \\
\text { Peer Relations } \\
\text { Questionnaire for } \\
\text { Children) does not } \\
\text { cover all domains of } \\
\text { peer relationships but } \\
\text { focuses on } \\
\text { adolescents' } \\
\text { experiences of } \\
\text { victimization, } \\
\text { bullying \& their own } \\
\text { prosocial behaviours. }\end{array}$ \\
\hline
\end{tabular}




\begin{tabular}{|c|c|c|c|c|c|c|c|}
\hline & & & & & & $\begin{array}{l}\text { - Interviews of } \\
\text { adolescents with co- } \\
\text { occurring DCD and } \\
\text { ADHD revealed they } \\
\text { feel lonely, are left out } \\
\text { by peers, and } \\
\text { experience } \\
\text { marginalization \& } \\
\text { victimization. }\end{array}$ & \\
\hline $\begin{array}{l}\text { Diamond et } \\
\text { al. [76] } \\
(2008)(\mathrm{USA})\end{array}$ & $\begin{array}{l}\text { Examine } \\
\text { children's } \\
\text { understanding } \\
\text { of the motor and } \\
\text { social } \\
\text { competence of } \\
\text { children with a } \\
\text { physical } \\
\text { disability, } \\
\text { children's } \\
\text { decision to } \\
\text { include or } \\
\text { exclude a peer } \\
\text { with a physical } \\
\text { disability, and } \\
\text { children's } \\
\text { justifications of } \\
\text { their inclusion } \\
\text { or exclusion } \\
\text { decisions. }\end{array}$ & $\begin{array}{l}\text { Inclusive } \\
\text { preschool and } \\
\text { child care } \\
\text { programs } \\
\text { 3-6 yrs } \\
\text { Mean age: } 4.4 \\
\text { yrs }\end{array}$ & $\begin{array}{l}\text { Interviews } \\
\text { Rating scale to } \\
\text { measure social } \\
\text { and motor } \\
\text { competence } \\
\text { Vignettes }\end{array}$ & $\begin{array}{l}\mathrm{n}=46 \\
\text { children with } \\
\text { and without } \\
\text { disabilities } \\
(56 \%)\end{array}$ & $\begin{array}{l}\text { Physical } \\
\text { disabilities } \\
\text { were focus of } \\
\text { interview } \\
\text { questions, } \\
\text { ratings, and } \\
\text { vignettes }\end{array}$ & $\begin{array}{l}\text { - More likely to choose } \\
\text { a typically developing } \\
\text { child vs. child with } \\
\text { disability. } \\
\text { - Girls more likely than } \\
\text { boys to choose a child } \\
\text { with a disability. } \\
\text { - Children gave higher } \\
\text { social competence than } \\
\text { motor skills ratings to } \\
\text { hypothetical child in } \\
\text { wheelchair. } \\
\text { - Motor skill } \\
\text { requirement of activity } \\
\text { was a factor in } \\
\text { decision for inclusion } \\
\text { by peer. } \\
\text { - Reasons for choosing } \\
\text { typically developing } \\
\text { child: (1) Absence of } \\
\text { equipment; (2) Use of } \\
\text { wheelchair (child is in } \\
\text { a wheelchair \& cannot } \\
\text { do it); (3) Ability to } \\
\text { participate in an } \\
\text { activity; (4) Disability } \\
\text { of hypothetical child in }\end{array}$ & $\begin{array}{l}\text { - Observations of } \\
\text { children's } \\
\text { interactions with } \\
\text { peers were not } \\
\text { conducted } \\
\text { (hypothetical } \\
\text { vignettes were used). }\end{array}$ \\
\hline
\end{tabular}




\begin{tabular}{|c|c|c|c|c|c|c|c|}
\hline & & & & & & $\begin{array}{l}\text { wheelchair; (5) } \\
\text { Sharing \& inclusion. }\end{array}$ & \\
\hline $\begin{array}{l}\text { Diamond and } \\
\text { Tu [74] } \\
\text { (2009) (USA) }\end{array}$ & $\begin{array}{l}\text { Examine how } \\
\text { children's } \\
\text { decisions to } \\
\text { include a peer } \\
\text { with a disability } \\
\text { are related to } \\
\text { play setting and } \\
\text { a child's } \\
\text { physical } \\
\text { disability. }\end{array}$ & $\begin{array}{l}\text { Inclusive } \\
\text { preschool } \\
\text { programs } \\
3-5 \mathrm{yrs} \\
\begin{array}{l}\text { Mean age: } \\
4.5 \mathrm{yrs}\end{array}\end{array}$ & $\begin{array}{l}\text { Vignette } \\
\text { interview } \\
\text { Motor skills } \\
\text { ratings }\end{array}$ & $\begin{array}{l}\mathrm{n}=68 \\
\text { children with } \\
\text { and without } \\
\text { disabilities } \\
(56 \%)\end{array}$ & $\begin{array}{l}\text { Physical } \\
\text { disabilities } \\
\text { were focus of } \\
\text { interview } \\
\text { questions, } \\
\text { ratings, and } \\
\text { vignettes }\end{array}$ & $\begin{array}{l}\text { - More likely to choose } \\
\text { typically developing } \\
\text { doll regardless of play } \\
\text { context (e.g., running). } \\
\text { - More likely to select } \\
\text { doll with disability } \\
\text { when disability did not } \\
\text { interfere with } \\
\text { participation. } \\
\text { - Girls more likely than } \\
\text { boys to select a child } \\
\text { with a disability } \\
\text { - Children referred most } \\
\text { to ability/ equipment to } \\
\text { explain choices } \\
\text { - Half changed selection } \\
\text { to the doll in the } \\
\text { wheelchair when } \\
\text { disability did not } \\
\text { interfere with } \\
\text { participation; } 33 \% \\
\text { chose the doll in the } \\
\text { wheelchair when use } \\
\text { of wheelchair } \\
\text { interfered with } \\
\text { participation. } \\
\text { - Selecting the doll in } \\
\text { the wheelchair } \\
\text { positively correlated } \\
\text { with explanations that } \\
\text { focused on sharing \& } \\
\text { enjoyment. }\end{array}$ & $\begin{array}{l}\text { - Sample } \\
\text { generalizability } \\
\text { (sample of children } \\
\text { with well-educated } \\
\text { parents). } \\
\text { - Observations of } \\
\text { children's } \\
\text { interactions with } \\
\text { peers or adults with } \\
\text { physical disabilities } \\
\text { were conducted. } \\
\text { - Do not know: (1) } \\
\text { extent to which } \\
\text { children's responses } \\
\text { to the counter-probes } \\
\text { reflected compliance } \\
\text { to the probe or a } \\
\text { reconsideration of } \\
\text { their inclusion } \\
\text { decision; and (2) } \\
\text { how children's } \\
\text { decisions in these } \\
\text { hypothetical } \\
\text { situations may be } \\
\text { related to actual } \\
\text { decisions to include } \\
\text { or exclude a peer } \\
\text { with a disability. }\end{array}$ \\
\hline
\end{tabular}




\begin{tabular}{|c|c|c|c|c|c|c|c|}
\hline $\begin{array}{l}\text { Diamond and } \\
\text { Hong [75] } \\
\text { (2010) (USA) }\end{array}$ & $\begin{array}{l}\text { Examine effect } \\
\text { of contextual } \\
\text { factors and } \\
\text { individual } \\
\text { characteristics } \\
\text { on preschool } \\
\text { children's } \\
\text { inclusion } \\
\text { decisions. }\end{array}$ & $\begin{array}{l}\begin{array}{l}\text { Inclusive } \\
\text { preschool } \\
\text { classrooms }\end{array} \\
3-5 \text { yrs } \\
\text { Mean age: } \\
4.25 \text { yrs }\end{array}$ & $\begin{array}{l}\text { Interview } \\
\text { (False-belief } \\
\text { tasks and } \\
\text { inclusion } \\
\text { interview) }\end{array}$ & $\begin{array}{l}\mathrm{n}=72 \\
\text { children with } \\
\text { and without } \\
\text { disabilities } \\
(51 \%)\end{array}$ & $\begin{array}{l}\text { Physical } \\
\text { disabilities } \\
\text { were focus of } \\
\text { interview } \\
\text { questions }\end{array}$ & $\begin{array}{l}\text { - More likely to say that } \\
\text { they would choose doll } \\
\text { without a physical } \\
\text { disability than the doll } \\
\text { in the wheelchair } \\
\text { across all contexts } \\
\text { (e.g., kicking a ball, } \\
\text { painting). } \\
\text { - More likely to choose } \\
\text { peer with disability } \\
\text { when: (1) Physical } \\
\text { disability interfered } \\
\text { minimally with the } \\
\text { activity; (2) Had } \\
\text { information about the } \\
\text { lack of experience of } \\
\text { the peer with a } \\
\text { disability. } \\
\text { - Children with low } \\
\text { theory of mind skills } \\
\text { less likely to include a } \\
\text { child with a disability } \\
\text { than children with high } \\
\text { theory of mind skills. } \\
\text { - Children more likely to } \\
\text { use moral justifications } \\
\text { related to equity \& } \\
\text { fairness when they } \\
\text { chose the doll in the } \\
\text { wheelchair. } \\
\end{array}$ & $\begin{array}{l}\text { - Generalization of } \\
\text { results is limited } \\
\text { (e.g., actual behavior } \\
\text { vs hypothetical } \\
\text { situation, to children } \\
\text { with types of } \\
\text { disabilities other than } \\
\text { physical). }\end{array}$ \\
\hline $\begin{array}{l}\text { Jessup et al. } \\
\text { [81] (2017) } \\
\text { (Australia) }\end{array}$ & $\begin{array}{l}\text { Explore the high } \\
\text { school social } \\
\text { experiences of } \\
\text { students with } \\
\text { visual } \\
\text { impairments }\end{array}$ & $\begin{array}{l}\text { High school } \\
13-17 \text { yrs } \\
\text { Grades 8-12 }\end{array}$ & $\begin{array}{l}\text { Questionnaires } \\
\text { Survey } \\
\text { completed } \\
\text { through an app } \\
\text { (completed 7x }\end{array}$ & $\begin{array}{l}\mathrm{n}=12 \text { high- } \\
\text { school } \\
\text { students with } \\
\text { impairments } \\
(58 \%)\end{array}$ & $\begin{array}{l}\text { Visually } \\
\text { impaired (12); } \\
\text { Additional } \\
\text { disabilities not } \\
\text { specified (3) }\end{array}$ & $\begin{array}{l}\text { - Students felt included } \\
\& \text { had a positive sense } \\
\text { of belonging. } \\
\text { - Reported being lonely } \\
\sim 1 / 3 \text { of the time } \\
\text { - Most frequent } \\
\text { activities: (1) School }\end{array}$ & $\begin{array}{l}\text { - Small sample limits } \\
\text { generalizability. } \\
\text { - Few participants had } \\
\text { multiple disabilities } \\
\text { as is representative } \\
\text { of this population of } \\
\text { adolescents. } \\
\end{array}$ \\
\hline
\end{tabular}




\begin{tabular}{|c|c|c|c|c|c|c|c|}
\hline & & & $\begin{array}{l}\text { daily for } 1 \\
\text { week) } \\
\text { Interviews }\end{array}$ & & & $\begin{array}{l}\text { work; (2) Talking; (3) } \\
\text { Doing nothing \& } \\
\text { engaging in extra- } \\
\text { curricular activities } \\
\text { (equal time spent). } \\
\text { - Almost half (44\%) of } \\
\text { all class interactions } \\
\text { involved students } \\
\text { receiving help. }\end{array}$ & - Self-selection bias. \\
\hline $\begin{array}{l}\text { Odom et al. } \\
\text { [77] (2006) } \\
\text { (USA) }\end{array}$ & $\begin{array}{l}\text { Study the social } \\
\text { acceptance and } \\
\text { rejection of } \\
\text { preschool } \\
\text { children with } \\
\text { disabilities }\end{array}$ & $\begin{array}{l}\text { Inclusive } \\
\text { preschool } \\
\text { programs } \\
\text { 3-5 yrs } \\
\text { Mean age: } 3.9 \\
\text { yrs }\end{array}$ & $\begin{array}{l}\text { Questionnaires } \\
\text { Observations } \\
\text { Semi- } \\
\text { structured } \\
\text { interviews }\end{array}$ & $\begin{array}{l}\mathrm{n}=80 \\
\text { children with a } \\
\text { disability } \\
(40 \%)\end{array}$ & $\begin{array}{l}\text { Speech- } \\
\text { language } \\
\text { impairment } \\
\text { (20), } \\
\text { Development- } \\
\text { al delay (13), } \\
\text { Mental } \\
\text { retardation } \\
\text { (12), } \\
\text { Physical } \\
\text { impairment } \\
\text { (11), } \\
\text { Autism (10), } \\
\text { Social- } \\
\text { emotional, } \\
\text { behavioural, } \\
\text { or attention } \\
\text { deficit } \\
\text { disorder (6), } \\
\text { Hearing } \\
\text { impairment } \\
\text { (2), } \\
\text { Visual } \\
\text { impairment } \\
\text { (3), } \\
\text { Health } \\
\text { impairment } \\
\text { (3) }\end{array}$ & $\begin{array}{l}\text { - } 28 \% \text { of children met } \\
\text { social acceptance } \\
\text { criteria established in } \\
\text { study. } \\
\text { - } 28 \% \text { were socially } \\
\text { rejected by peer group. } \\
\text { - } 14 \text { themes related to } \\
\text { social acceptance } \\
\text { grouped into } 3 \\
\text { clusters: (1) } \\
\text { Awareness \& interest } \\
\text { in peers \& classroom } \\
\text { context; (2) } \\
\text { Communication skill } \\
\text { \& pretend play skill; } \\
\text { (3) Social } \\
\text { abilities/Friendship. } \\
\text { - Eight social rejection } \\
\text { themes: grouped into } \\
\text { two clusters: (1) Social } \\
\text { withdrawal-Isolation; } \\
\text { (2) Conflict- } \\
\text { Aggression. } \\
\text { - Children who had } \\
\text { disabilities that } \\
\text { affected social } \\
\text { problem-solving or } \\
\text { emotion regulation }\end{array}$ & $\begin{array}{l}\text { - Small sample limits } \\
\text { generalizability. } \\
\text { - Inter-observer } \\
\text { agreement was low. }\end{array}$ \\
\hline
\end{tabular}




\begin{tabular}{|c|c|c|c|c|c|c|c|}
\hline & & & & & & $\begin{array}{l}\text { more likely to be } \\
\text { socially rejected vs. } \\
\text { those who did not } \\
\text { (e.g., Physical } \\
\text { impairment). }\end{array}$ & \\
\hline $\begin{array}{l}\text { Tsang [82] } \\
\text { (2013) (Hong } \\
\text { Kong) }\end{array}$ & $\begin{array}{l}\text { Examine and } \\
\text { compare } \\
\text { attitudes and } \\
\text { perceptions of } \\
\text { secondary } \\
\text { students with } \\
\text { and without } \\
\text { special } \\
\text { education needs } \\
\text { towards } \\
\text { studying } \\
\text { together on the } \\
\text { same campus. }\end{array}$ & $\begin{array}{l}\text { Inclusive } \\
\text { secondary } \\
\text { school }\end{array}$ & $\begin{array}{l}\text { Questionnaire } \\
\text { Open-ended } \\
\text { questions of } \\
\text { same } \\
\text { questionnaire }\end{array}$ & 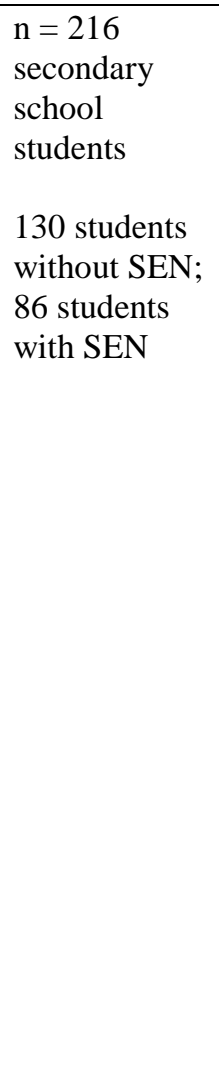 & SEN & $\begin{array}{l}\text { - For students with and } \\
\text { without disabilities, } \\
\text { inclusion of peers with } \\
\text { physical disabilities is } \\
\text { more accepted than } \\
\text { inclusion of disruptive } \\
\text { or aggressive peers. } \\
\text { - Both groups perceive } \\
\text { that studying together } \\
\text { in the same classroom } \\
\text { has: (1) A positive } \\
\text { impact on promoting } \\
\text { students' social } \\
\text { relationships between } \\
\text { the two groups; (2) A } \\
\text { negative impact on } \\
\text { progress of learning } \\
\text { performance. } \\
\text { - Four themes: (1) Lack } \\
\text { of social interactive } \\
\text { initiatives; (2) Lack of } \\
\text { mutual understanding; } \\
\text { (3) Lack of social } \\
\text { participation } \\
\text { opportunities; (4) Lack } \\
\text { of social coping skills } \\
\text { in bullying situations. }\end{array}$ & $\begin{array}{l}\text { - Unrepresentative } \\
\text { sample. }\end{array}$ \\
\hline
\end{tabular}


Table 4. Social inclusion strategies used and suggested by peers

\begin{tabular}{|c|c|}
\hline Peer strategies used & Study \\
\hline Taking initiative (e.g., saying hello, lending a hand) & Tsang [82] \\
\hline $\begin{array}{l}\text { Being persistent in interactions \& following the lead of children with } \\
\text { disability }\end{array}$ & Parry [62] \\
\hline $\begin{array}{l}\text { Being supportive: } \\
\text { - Helping the child (e.g., read to child, "walk" child to playground, help } \\
\text { child to play sports, games, or participate in social interactions) } \\
\text { - Providing encouragement } \\
\text { - Giving advice }\end{array}$ & $\begin{array}{l}\text { Naraian [60]; Nowicki \& } \\
\text { Brown [72]; Anderson et al. } \\
{[70]}\end{array}$ \\
\hline $\begin{array}{l}\text { Making sure child is still included if unable to participate: } \\
\text { - Including the child in parts of the activity } \\
\text { - Assigning the child alternative role (e.g., cheerleader) }\end{array}$ & Anderson et al. [70] \\
\hline $\begin{array}{l}\text { Choosing an easy activity/game } \\
\text { Modifying the activity/game (e.g., rules) } \\
\text { Adjusting own behavior or task so activity can be completed (e.g., take } \\
\text { most advanced task) } \\
\text { Adjusting everyone's tasks so child gets task he/she can do }\end{array}$ & $\begin{array}{l}\text { Dolva et al. [51]; Seymour et } \\
\text { al. [68] }\end{array}$ \\
\hline $\begin{array}{l}\text { Asking the teacher for help when communicating with a child with } \\
\text { disability }\end{array}$ & Anderson et al. [70] \\
\hline Adjusting to child's pace when walking with a child with disability & Asbjornslett et al. [46] \\
\hline Sharing small-talk about mutual interests & Asbjornslett et al. [46] \\
\hline $\begin{array}{l}\text { Engaging in collaborative activities that facilitate spending time } \\
\text { together/interaction }\end{array}$ & $\begin{array}{l}\text { Morrison \& Burgman [58]; } \\
\text { Tsang [82] }\end{array}$ \\
\hline \multicolumn{2}{|l|}{ Peer strategies suggested } \\
\hline \multicolumn{2}{|l|}{ Learning and sharing information about disabilities } \\
\hline $\begin{array}{l}\text { Taking the role of a peer tutor (e.g., take book \& pronounce words slowly, } \\
\text { daily reading/practice of math skills) } \\
\text { - Breaking down tasks/teaching into steps and in a way child will } \\
\text { understand } \\
\text { - Give them more time to do their work and/or learn }\end{array}$ & $\begin{array}{l}\text { Nowicki \& Brown [72]; } \\
\text { Shokoohi-Yekta \& } \\
\text { Hendrickson [45] }\end{array}$ \\
\hline $\begin{array}{l}\text { Approaching child with disability in a "kid way" (teachers do it in a } \\
\text { "grown-up way") }\end{array}$ & Nowicki \& Brown [72] \\
\hline Focusing on similarities, not differences & Nowicki \& Brown [72] \\
\hline Modeling appropriate social behaviour (e.g., being respectful, kind) & Nowicki \& Brown [72] \\
\hline $\begin{array}{l}\text { Intervening in non-appropriate social behaviours (e.g., } \\
\text { aggression/bullying) }\end{array}$ & Nowicki \& Brown [72] \\
\hline $\begin{array}{l}\text { Engaging in collaborative activities (e.g., group work, inclusion in } \\
\text { intramurals or school clubs) }\end{array}$ & $\begin{array}{l}\text { Nowicki \& Brown [72]; } \\
\text { Kalymon et al. [71]; } \\
\text { Shokoohi-Yekta \& } \\
\text { Hendrickson [45] }\end{array}$ \\
\hline \multicolumn{2}{|l|}{ Teacher strategies suggested } \\
\hline $\begin{array}{l}\text { Intervening to facilitate inclusion (e.g., bring child with disability to the } \\
\text { group, pick groups) }\end{array}$ & Nowicki \& Brown [72] \\
\hline
\end{tabular}


Author accepted manuscript: Disability and Rehabilitation, $17^{\text {th }}$ December 2018

Providing instructional assistance to facilitate inclusion (e.g., read as a class or group, ensure child has an educational assistance)

Educating children about disabilities

Nowicki \& Brown [72]

Nowicki \& Brown [72] 
Table 5. Barriers and supports to social inclusion reported by children with disabilities

\begin{tabular}{|c|c|}
\hline Barriers & Study \\
\hline \multicolumn{2}{|l|}{ Disability-related } \\
\hline Assistive technology when viewed as intimidating & Batorowicz et al. [47] \\
\hline \multicolumn{2}{|l|}{ Classroom supports } \\
\hline $\begin{array}{l}\text { Teacher assistance (e.g., cannot chat with peers) } \\
\text { Class routines (e.g., changing seating position to accommodate needs) } \\
\text { Practices of schooling (e.g., grading \& academic-ability grouping) and } \\
\text { differentiation strategies (e.g., support assistants, withdrawing child from } \\
\text { class for being disruptive }\end{array}$ & $\begin{array}{l}\text { De Boer et al. [39] } \\
\text { Kamenopoulou [54] } \\
\text { MacArthur et al. [56]; } \\
\text { McMaugh [57]; } \\
\text { Morrison \& Burgman [58] }\end{array}$ \\
\hline \multicolumn{2}{|l|}{ Social Supports } \\
\hline Support from an adult preventing interaction with students/participation & Mortier et al. [66] \\
\hline $\begin{array}{l}\text { Dependence on parental involvement in best friendships (e.g., for } \\
\text { transportation) }\end{array}$ & $\begin{array}{l}\text { Seymour et al. [68]; } \\
\text { McMaugh [57] }\end{array}$ \\
\hline Supports & Study \\
\hline \multicolumn{2}{|l|}{ Classroom supports } \\
\hline Studying together in same classroom & Tsang [82] \\
\hline Having a friendly and positive teacher & $\begin{array}{l}\text { Morrison \& Burgman [58]; } \\
\text { O'Rourke \& Houghton [43] }\end{array}$ \\
\hline $\begin{array}{l}\text { Having support people in the classroom } \\
\text { Instructional strategies (e.g., clear and effective teaching, making the } \\
\text { subject interesting, working with peers on projects) }\end{array}$ & $\begin{array}{l}\text { De Schauwer et al. [50]; } \\
\text { Jessup et al. [81]; } \\
\text { O’Rourke \& Houghton [43] }\end{array}$ \\
\hline \multicolumn{2}{|l|}{ Social Supports } \\
\hline $\begin{array}{l}\text { Influence of adults and peers on opportunities to participate } \\
\text { Parental Involvement: } \\
\text { - facilitate social contact (e.g., invite peers over) } \\
\text { - offer advice on how to interact with others } \\
\text { - arrange play dates and facilitate access to structured activities } \\
\text { - } \quad \text { seek families in similar situations \& encourage friendship } \\
\text { development } \\
\text { Classmates as source of support (e.g., physical } \\
\text { assistance, help with homework) }\end{array}$ & $\begin{array}{l}\text { Spencer-Cavaliere \& } \\
\text { Watkinson [63]; } \\
\text { Asbjornslett et al. [46]; } \\
\text { Batorowicz et al. [47]; } \\
\text { Howard et al. [53]; Naraian } \\
\text { [60]; Spencer-Cavaliere \& } \\
\text { Watkinson [63]; } \\
\text { De Schauwer et al. [50]; } \\
\text { Jessup et al. [81]; Seymour et } \\
\text { al. [68]; Spratling et al. [64]; } \\
\text { Dolva et al. [51] }\end{array}$ \\
\hline $\begin{array}{l}\text { Friends as source of companionship, instrumental (e.g., help with } \\
\text { homework), and emotional (e.g., relationship advice) support } \\
\text { Activities that are structured, simple, or well-known to participants } \\
\text { Shared understanding of the activity, ability to perform the activity, } \\
\text { interest, and motivation } \\
\text { Educating others about disabilities and familiarity } \\
\text { Internet and cell phones to maintaining intimacy in relationships }\end{array}$ & $\begin{array}{l}\text { Dolva et al. [51] } \\
\text { Batorowicz et al. [47]; } \\
\text { Spratling et al. [64]; } \\
\text { Asbjornslett et al. [46] }\end{array}$ \\
\hline
\end{tabular}


Table 6. Strategies used by children with disabilities to facilitate social inclusion

\begin{tabular}{|c|c|}
\hline Strategies & Study \\
\hline Keeping activities as normal as possible & Mortier et al. [66] \\
\hline Expressing needs/preferences & $\begin{array}{l}\text { MacArthur et al. } \\
\text { [56]; Mortier et al. } \\
\text { [66] }\end{array}$ \\
\hline Emphasizing similarities with peers rather than differences & $\begin{array}{l}\text { De Schauwer et al. } \\
\text { [50]; MacArthur et } \\
\text { al. [56] }\end{array}$ \\
\hline Hiding or 'masking' their disability & $\begin{array}{l}\text { Cook et al. [48]; } \\
\text { Murphy et al. [59]; } \\
\text { Sumiya et al. [65] }\end{array}$ \\
\hline Avoiding the use of equipment that may make them appear different & $\begin{array}{l}\text { Asbjornslett et al. } \\
\text { [46]; MacArthur et } \\
\text { al. [56] }\end{array}$ \\
\hline Educating others about disabilities & Spratling et al. [64] \\
\hline $\begin{array}{l}\text { Resisting disabling experiences: } \\
\text { - Challenging low expectations, attitudes, behaviors, structures \& } \\
\text { experiences that discriminate against them } \\
\text { - Defending themselves (e.g., digging nails into peers, using } \\
\text { profanities) } \\
\text { - Negotiating } \\
\text { - Using humour }\end{array}$ & $\begin{array}{l}\text { MacArthur et al. } \\
\text { [56]; } \\
\text { McMaugh [57] }\end{array}$ \\
\hline 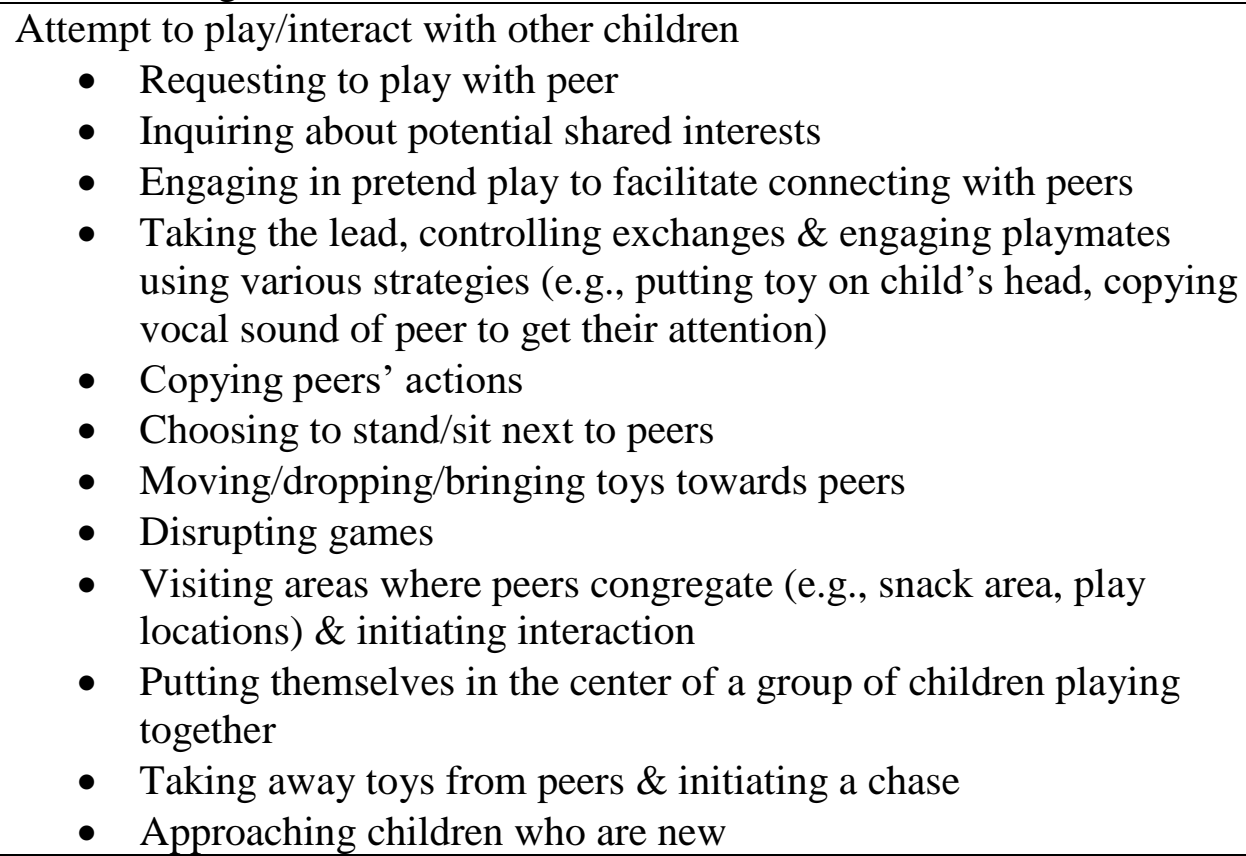 & $\begin{array}{l}\text { Kayama \& Haight } \\
\text { [55]; Parry [62]; } \\
\text { Parry [67]; Dolva et } \\
\text { al. [51] }\end{array}$ \\
\hline
\end{tabular}


Figure 1. Information Flow through the Different Phases of the Systematic Review

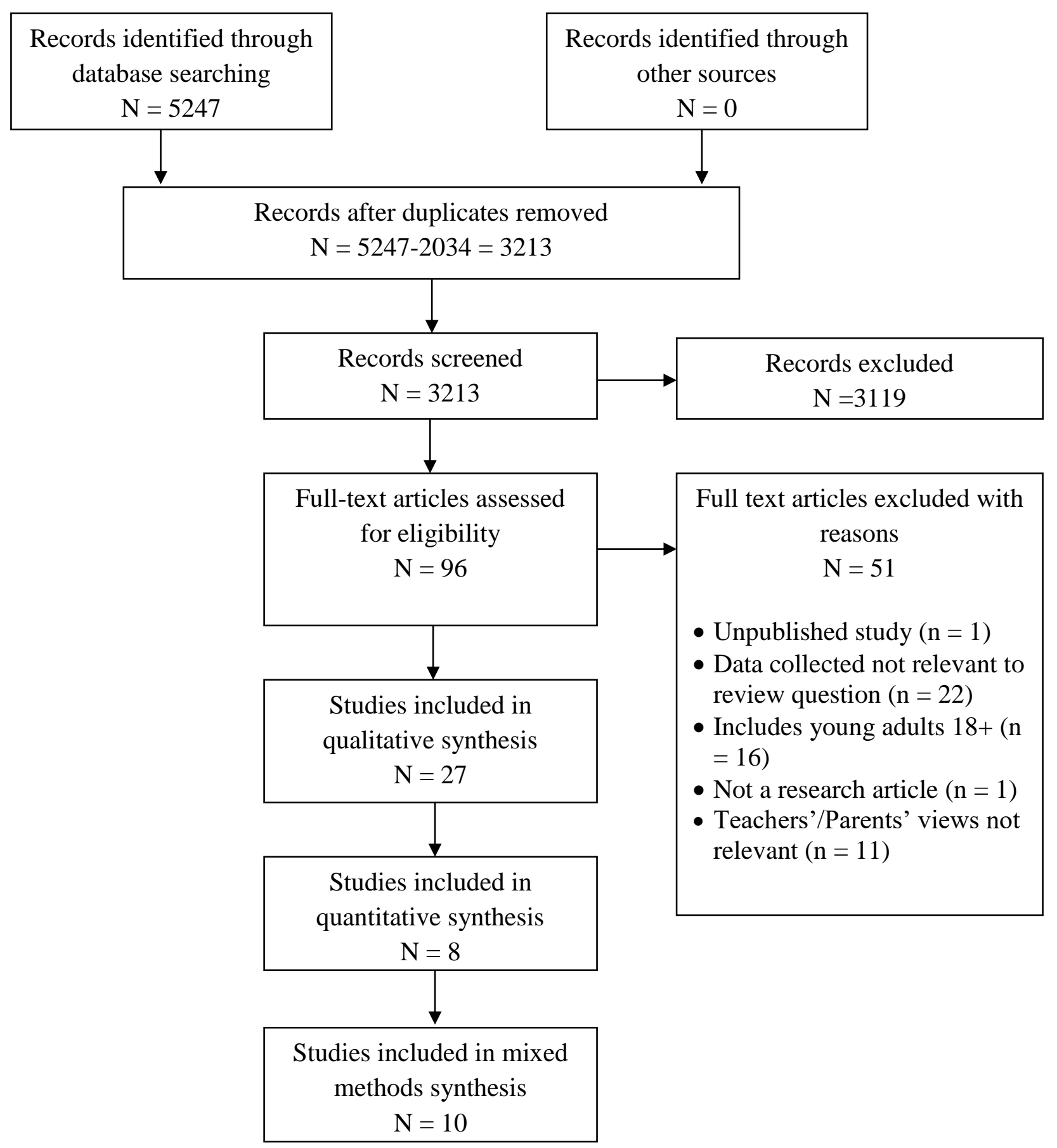

